\title{
Article \\ Tyrosinase Inhibitory and Antioxidant Activity of Enzymatic Protein Hydrolysate from Jellyfish (Lobonema smithii)
}

\author{
Maytamart Upata ${ }^{1}\left(\mathbb{D}\right.$, Thanyaporn Siriwoharn ${ }^{1}$, Sakunkhun Makkhun ${ }^{2}$, Suthasinee Yarnpakdee ${ }^{1}$, \\ Joe M. Regenstein ${ }^{3}$ (D) and Sutee Wangtueai ${ }^{4, *}$ \\ 1 Faculty of Agro-Industry, Chiang Mai University, Chiang Mai 50100, Thailand \\ deariimaytamart@hotmail.co.th (M.U.); thanyaporn.s@cmu.ac.th (T.S.); suthasinee.y@cmu.ac.th (S.Y.) \\ 2 Faculty of Agriculture and Natural Resources, University of Phayao, Phayao 56000, Thailand; \\ sakunkhun.ma@up.ac.th \\ 3 Department of Food Science, College of Agriculture and Life Science, Cornell University, \\ Ithaca, NY 14853-7201, USA; jmr9@cornell.edu \\ 4 College of Maritime Studies and Management, Chiang Mai University, Samut Sakhon 74000, Thailand \\ * Correspondence: sutee.w@cmu.ac.th; Tel.: +66-34-87-0708; Fax: +66-34-87-0710
}

check for updates

Citation: Upata, M.; Siriwoharn, T.;

Makkhun, S.; Yarnpakdee, S.;

Regenstein, J.M.; Wangtueai, S.

Tyrosinase Inhibitory and

Antioxidant Activity of Enzymatic

Protein Hydrolysate from Jellyfish

(Lobonema smithii). Foods 2022, 11, 615

https://doi.org/10.3390/

foods11040615

Academic Editor: Maria Hayes

Received: 3 February 2022

Accepted: 17 February 2022

Published: 21 February 2022

Publisher's Note: MDPI stays neutral with regard to jurisdictional claims in published maps and institutional affiliations.

Copyright: (C) 2022 by the authors. Licensee MDPI, Basel, Switzerland. This article is an open access article distributed under the terms and conditions of the Creative Commons Attribution (CC BY) license (https:// creativecommons.org/licenses/by/ $4.0 /$ )

\begin{abstract}
The optimization of antioxidant and anti-tyrosinase activity during jellyfish hydrolysate preparation was studied using a response surface methodology (RSM) with a face-centered composite design. The influence of the hydrolysis duration and the enzyme concentration on the $\mathrm{IC}_{50}$ of the DPPH and ABTS radical scavenging activity, ferric-reducing antioxidant power (FRAP), the degree of hydrolysis $(\mathrm{DH})$, yield, and the $\mathrm{IC}_{50}$ value of tyrosinase inhibitory activity were determined. The optimum conditions for the production of jellyfish hydrolysate using alcalase (JFAH), flavourzyme (JFFH), or papain (JFPH) were achieved at hydrolysis times of 360, 345, or $360 \mathrm{~min}$, respectively, and at an enzyme concentration of 5.0\%. JFFH had the highest antioxidant and tyrosinase inhibitory activity. JFAH, JFFH, and JFPH concentrations of $2.5 \mathrm{mg} / \mathrm{mL}$ resulted in HaCaT cells $\left(\mathrm{IC}_{80}\right)$ having a survival rate of $80 \%$. The amino acid profile of JFFH contained about $43 \%$ hydrophobic and $57 \%$ hydrophilic amino acids, comprising Gly, Cys, Glx, Asx, which were dominant. The isolation of a peptide fraction from JFFH was carried out using ultrafiltration membranes (10, 3, and $1 \mathrm{kDa})$ and gel filtration chromatography. Fraction-III (1-3 kDa) showed the highest antioxidative and tyrosinase inhibitory activity.
\end{abstract}

Keywords: antioxidant activity; anti-tyrosinase activity; protein hydrolysate; jellyfish; alcalse; flavourzyme; papain; Lobonema smithii

\section{Introduction}

Tyrosinase, a copper-containing molecule, is an essential enzyme in melanin formation that accelerates the generation of melanin from tyrosine via oxidation. The enzyme is predominantly involved in two melanin production reactions, i.e., the monophenolase reaction involving the hydroxylation of tyrosine and the diphenolase reaction for the oxidation of 3,4-dihydroxyl-L-phenylalanine (L-DOPA) to dopaquinone [1]. Melanin is a pigment that is found in bacteria, fungals, plants, and mammals. Tyrosinase activity is necessary for the provision of melanosomes into keratinocytes, and melanogenesis modulators can directly affect this activity [2]. Therefore, limiting tyrosinase activity in cosmetics and medicine can prevent the browning of foods and melanin synthesis [3]. The development and screening of tyrosinase inhibitors to be used as cosmetics products and food additives has been of interest in the industrial sector [4-6].

Edible jellyfish have been consumed throughout Southeast Asia for more than a thousand years $[7,8]$. The total world capture production of edible jellyfish in 2015-2018 was estimated to be $\sim 300,000$ tonnes/year [9]. Most commercial jellyfish are processed using a traditional method involving alum salt dehydration before producing the product 
as being canned in brine, semi-dried, or dry-salted [8]. White jellyfish (Lobonema smithii) are one of the main edible species of jellyfish in Asia. In Thailand, it is used to produce a salted jellyfish product for both domestic consumption and for export to other consumer countries, i.e., Taiwan, China, Malaysia, South Korea, and Japan, with a value about USD 10 million annually [10,11]. Jellyfish are abundant in collagenous protein, have a high nutritional value, and is capable of pharmacological activities that might imply a wider range of applications in the food, cosmetic, and pharmaceutical industries [7,12]. In China, it has been utilized for the treatment of bronchitis, high blood pressure, tracheitis, asthma, and gastric ulcers [13]. Type I collagen and type A gelatin from jellyfish have been prepared and characterized for further applications [11,14,15]. Based on the supply and potential health benefits, jellyfish may be used to develop functional ingredients for health foods, including nutraceutical products.

Protein hydrolysates are chemically or enzymatically produced and yield free amino acids or short peptides. Hydrolysis using enzymes has been utilized to obtain nutritional and bioactive peptides $[16,17]$. The antioxidant and tyrosinase inhibition activity of protein hydrolysates and peptides from marine resources have shown strong antioxidant activity and have been applied as natural antioxidants $[18,19]$. They have also been shown to be tyrosinase inhibitors with low adverse side effects [4]. Jellyfish collagen hydrolysates and peptides demonstrate antioxidant activity [7,12,20,21], melanogenesis inhibition [12], tyrosinase inhibition [21], anti-fatigue activities [7], UV protection [14], and angiotensin converting enzyme (ACE) inhibitory activity [22]. However, these peptides from white jellyfish have not been characterized, nor have preparative methods been maximized for tyrosinase inhibitory and antioxidant activities.

The aim of this research was to develop value-added products from low-value salted white jellyfish from Thailand for potential applications in the food, cosmetics, and pharmaceutical industries. Therefore, the production of jellyfish hydrolysates with tyrosinase inhibitory and antioxidant activity was optimized using enzymatic hydrolysis and peptide isolation.

\section{Materials and Methods}

\subsection{Raw Material and Preparation}

Alum-salted jellyfish (Lobonema smithii) was obtained from Siam Jellyfish Co., Ltd., Samut Sakhon, Thailand. It was contained in a sealed high-density polyethylene (HDPE) bucket (size $18 \mathrm{~kg}$ ). To desalt the jellyfish, the sample was initially cleaned under running tap water and was soaked in water (jellyfish:water $=1: 2$ ) overnight $(12-14 \mathrm{~h}$ ). The soaked jellyfish was cleaned under running tap water until the salt content in wash water was approximately zero. The salt content was measured using a salinometer (Master-S28 M, Atago ${ }^{\circledR}$, Tokyo, Japan), and the water was drained for 30 min to obtain the desalted jellyfish. The jellyfish were ground using a blender (Daily Collection HR7627 Blender, Philips, Bangkok, Thailand) and were packed in Zip-lock polyethylene bags and stored at -18 to $-20{ }^{\circ} \mathrm{C}$ until use (<2 months).

\subsection{Chemical and Enzymes}

Papain ( $\geq 3$ activity units (AU)/mg), Alcalase $2.4 \mathrm{~L}[\geq 2.4(\mathrm{AU}) / \mathrm{g}]$, flavourzyme ( $\geq 500 \mathrm{AU} / \mathrm{g}$ ), tyrosinase from mushroom, 1,1-diphenyl-2-picrylhydrazyl (DPPH), ferric chloride hexahydrate $\left(\mathrm{FeCl}_{3} \bullet 6 \mathrm{H}_{2} \mathrm{O}\right), 2,2$ ' azinobis(3-ethylbenzothiazoline-6-sulfonic acid) (ABTS), 2,4,5-tripyridyl-triazine (TPTZ), 2,4,6-trinitrobenzenesulfonic acid (TNBS), kojic acid, and 3,4-dihydroxy-L-phenylalanine were purchased from Sigma-Aldrich (St. Louis, MO, USA). Fetal bovine serum (FBS), penicillin, dulbecco's modified eagle medium (DMEM), and L-glutamine were purchased from XL Biotec Co., Ltd. (Bangkok, Thailand). All of the chemicals and reagents used were of analytical grade. 


\subsection{Chemical Composition Analysis}

The chemical composition of desalted jellyfish was determined according to the official AOAC method (2000): 934.01 moisture, 954.01 crude protein, 991.36 lipids, and 942.05 ash. Nitrogen was converted to crude protein using a conversion factor of 6.25.

\subsection{Optimization of the Production of Jellyfish Hydrolysate (JFH)}

The desalted jellyfish was hydrolyzed using three different proteases. The effect of the enzyme concentration (1-5\% $w / w$ protein content) and hydrolysis time (60-360 min) on the yield, DH, FRAP value, and antioxidant and tyrosinase inhibition activity were determined. For the hydrolysis process, a mixture of $50 \mathrm{~g}$ desalted jellyfish and $100 \mathrm{~mL}$ distilled water $(w: v=1: 2)$ was terminated for endogenous enzymes by heating it at $95{ }^{\circ} \mathrm{C}$ for $15 \mathrm{~min}$ cooling it to the optimum temperature of each enzyme (papain and flavozyme at $50{ }^{\circ} \mathrm{C}$ and alcalase at $60^{\circ} \mathrm{C}$ ), and hydrolyzing it following the experimental design. The reaction was carried out in a shaking incubator (Memmert WNB45, Schwabach, Germany) with constant agitation for 60-360 min (Table 1). After hydrolysis, the reaction of the hydrolysate solution was stopped by heating it at $95{ }^{\circ} \mathrm{C}$ for $15 \mathrm{~min}$, and it was then cooled under running tab water. Thereafter, the hydrolysate solution was centrifuged at $5500 \times g$ for $15 \mathrm{~min}$ (1736R, LaboGene, Lynge, Denmark). The supernatant was lyophilized using a freeze-dryer (GRISRIANTHONG, GFD-3H, Samut Sakhon, Thailand). The jellyfish hydrolysate powder that was obtained was packed in Zip-lock polyethylene bags and kept at $-20{ }^{\circ} \mathrm{C}$ until further investigation.

Table 1. Experimental units and response variables for DH, yield, DPPH and ABTS radical scavenging activity, FRAP value, and tyrosinase inhibitory activity of jellyfish protein hydrolyzed using alcalase, flavourzyme, and papain.

\begin{tabular}{|c|c|c|c|c|c|c|c|c|c|}
\hline \multirow[b]{2}{*}{ Enzyme } & \multirow[b]{2}{*}{ Treatment } & \multicolumn{2}{|c|}{ Factors } & \multicolumn{6}{|c|}{ Responses } \\
\hline & & $X_{1}$ & $X_{2}$ & $\% \mathrm{DH}$ & \%Yield & $\begin{array}{c}\mathrm{DPPH} \\
\left(\mathrm{IC}_{50}\right)(\mathrm{mg} / \mathrm{mL})\end{array}$ & $\begin{array}{c}\text { ABTS } \\
\left(\mathrm{IC}_{50}\right)(\mathrm{mg} / \mathrm{mL})\end{array}$ & $\begin{array}{c}\text { FRAP } \\
\left(\mathrm{mmol}^{2}\right. \\
\left.\mathrm{FeSO}_{4} / \mathrm{g}\right)\end{array}$ & $\begin{array}{c}\text { Anti- } \\
\text { Tyrosinase } \\
\left(\mathrm{IC}_{50}\right)(\mathrm{mg} / \mathrm{mL})\end{array}$ \\
\hline \multirow{11}{*}{ Alcalase } & 1 & 60 & 1 & $14.0^{b} \pm 0.2$ & $1.17^{\mathrm{a}} \pm 0.23$ & $0.54^{\mathrm{a}} \pm 0.26$ & $5.23^{g} \pm 0.20$ & $0.24^{\mathrm{h}} \pm 0.03$ & $23.2^{\mathrm{d}} \pm 0.6$ \\
\hline & 2 & 360 & 1 & $11.1^{\mathrm{a}} \pm 0.2$ & $1.12^{\mathrm{a}} \pm 0.23$ & $0.42^{\mathrm{a}} \pm 0.07$ & $6.03^{\text {gh }} \pm 1.69$ & $0.19^{\mathrm{e}} \pm 0.03$ & $22.9^{c} \pm 0.5$ \\
\hline & 3 & 60 & 5 & $29.8^{g} \pm 0.1$ & $2.27^{\mathrm{d}} \pm 0.52$ & $1.02^{b} \pm 0.17$ & $3.70^{\text {def }} \pm 0.92$ & $0.21^{\mathrm{f}} \pm 0.02$ & $26.0^{\text {de }} \pm 0.7$ \\
\hline & 4 & 360 & 5 & $25.5^{\mathrm{e}} \pm 0.1$ & $2.93^{f} \pm 0.80$ & $2.15^{\mathrm{cd}} \pm 0.43$ & $1.07^{\mathrm{a}} \pm 0.02$ & $0.13^{a} \pm 0.01$ & $11.4^{\mathrm{a}} \pm 0.1$ \\
\hline & 5 & 60 & 3 & $28.4^{\mathrm{f}} \pm 0.1$ & $2.03^{\mathrm{d}} \pm 0.32$ & $2.35^{\mathrm{d}} \pm 0.18$ & $3.17^{\mathrm{de}} \pm 0.57$ & $0.22^{g} \pm 0.07$ & $13.7^{\mathrm{a}} \pm 1.0$ \\
\hline & 6 & 360 & 3 & $33.2^{\mathrm{i}} \pm 1.7$ & $2.81^{\mathrm{f}} \pm 0.84$ & $7.70^{\mathrm{e}} \pm 2.47$ & $1.43^{b} \pm 0.17$ & $0.13^{\mathrm{a}} \pm 0.01$ & $25.5^{\mathrm{e}} \pm 0.2$ \\
\hline & 7 & 210 & 1 & $19.7^{c} \pm 0.1$ & $1.43^{b} \pm 0.12$ & $1.50^{\mathrm{bc}} \pm 1.18$ & $2.02^{b c} \pm 1.63$ & $0.19^{\mathrm{e}} \pm 0.03$ & $30.8^{g} \pm 0.7$ \\
\hline & 8 & 210 & 5 & $31.4^{\mathrm{h}} \pm 0.1$ & $2.69^{\text {ef }} \pm 0.46$ & $0.92^{\mathrm{ab}} \pm 0.43$ & $4.02^{\text {ef }} \pm 1.04$ & $0.17^{c} \pm 0.02$ & $28.9^{\mathrm{fg}} \pm 1.9$ \\
\hline & 9 & 210 & 3 & $28.2^{\mathrm{f}} \pm 0.1$ & $2.97^{\mathrm{f}} \pm 0.11$ & $2.40^{\mathrm{d}} \pm 0.36$ & $4.63^{f} \pm 0.23$ & $0.14^{b} \pm 0.01$ & $23.9^{\mathrm{d}} \pm 0.1$ \\
\hline & 10 & 210 & 3 & $24.1^{\mathrm{d}} \pm 0.1$ & $2.97^{\mathrm{f}} \pm 0.18$ & $2.14^{\mathrm{cd}} \pm 0.27$ & $5.21^{\mathrm{g}} \pm 0.40$ & $0.13^{\mathrm{a}} \pm 0.01$ & $25.7^{\text {de }} \pm 1.8$ \\
\hline & 11 & 210 & 3 & $31.3^{\mathrm{h}} \pm 0.1$ & $1.76^{\mathrm{bc}} \pm 0.32$ & $1.14^{b} \pm 0.08$ & $2.97^{c} \pm 0.30$ & $0.18^{\mathrm{d}} \pm 0.02$ & $20.5^{\mathrm{b}} \pm 0.1$ \\
\hline \multirow{11}{*}{ Flavourzyme } & 1 & 60 & 1 & $29.1^{\mathrm{a}} \pm 0.1$ & $1.55^{\mathrm{a}} \pm 0.03$ & $1.16^{b c} \pm 0.28$ & $11.1^{\text {ef }} \pm 2.8$ & $0.14^{\mathrm{d}} \pm 0.01$ & $43.8^{j} \pm 0.1$ \\
\hline & 2 & 360 & 1 & $40.8^{c} \pm 0.0$ & $2.50^{\mathrm{b}} \pm 0.11$ & $0.63^{a} \pm 0.07$ & $20.6^{g} \pm 1.2$ & $0.14^{\mathrm{d}} \pm 0.01$ & $22.7^{b c} \pm 0.5$ \\
\hline & 3 & 60 & 5 & $42.7^{\mathrm{d}} \pm 0.1$ & $3.65^{\text {ef }} \pm 0.24$ & $2.22^{\mathrm{e}} \pm 0.88$ & $9.76^{\mathrm{e}} \pm 0.91$ & $0.13^{c} \pm 0.01$ & $29.4^{\mathrm{f}} \pm 0.5$ \\
\hline & 4 & 360 & 5 & $44.3^{\mathrm{f}} \pm 0.1$ & $5.15^{\mathrm{g}} \pm 0.28$ & $0.86^{\mathrm{b}} \pm 0.07$ & $5.91^{b c} \pm 0.14$ & $0.14^{\mathrm{d}} \pm 0.01$ & $13.5^{\mathrm{cd}} \pm 0.5$ \\
\hline & 5 & 60 & 3 & $43.0^{\mathrm{e}} \pm 0.0$ & $2.88^{b} \pm 0.14$ & $1.75^{\mathrm{d}} \pm 0.24$ & $7.74^{\mathrm{d}} \pm 0.88$ & $0.14^{\mathrm{d}} \pm 0.01$ & $30.1^{\text {gh }} \pm 1.4$ \\
\hline & 6 & 360 & 3 & $45.7^{g} \pm 0.3$ & $3.97^{\mathrm{f}} \pm 0.15$ & $2.57^{\mathrm{ef}} \pm 1.24$ & $12.9^{\mathrm{f}} \pm 0.7$ & $0.13^{c} \pm 0.01$ & $23.2^{\mathrm{c}} \pm 1.3$ \\
\hline & 7 & 210 & 1 & $43.1^{\mathrm{e}} \pm 0.1$ & $3.30^{c} \pm 0.12$ & $2.41^{\text {ef }} \pm 1.34$ & $4.15^{b} \pm 1.11$ & $0.17^{\mathrm{f}} \pm 0.05$ & $35.8^{\mathrm{i}} \pm 0.4$ \\
\hline & 8 & 210 & 5 & $38.1^{b} \pm 0.1$ & $5.63^{g} \pm 1.18$ & $4.66^{h} \pm 0.17$ & $2.49^{a} \pm 0.31$ & $0.15^{\mathrm{e}} \pm 0.02$ & $33.5^{h} \pm 0.2$ \\
\hline & 9 & 210 & 3 & $45.3^{g} \pm 0.1$ & $3.40^{\mathrm{d}} \pm 0.20$ & $1.50^{\mathrm{d}} \pm 0.08$ & $5.26^{b} \pm 1.68$ & $0.12^{b} \pm 0.02$ & $22.5^{b} \pm 0.2$ \\
\hline & 10 & 210 & 3 & $44.9^{\mathrm{f}} \pm 0.1$ & $3.57^{\text {e }} \pm 0.12$ & $2.71^{\mathrm{f}} \pm 0.41$ & $6.03^{c} \pm 0.14$ & $0.11^{\mathrm{a}} \pm 0.02$ & $20.7^{\mathrm{a}} \pm 0.7$ \\
\hline & 11 & 210 & 3 & $42.2^{\mathrm{de}} \pm 0.1$ & $5.02^{g} \pm 0.39$ & $2.79^{\mathrm{f}} \pm 0.52$ & $2.51^{\mathrm{a}} \pm 0.08$ & $0.16^{\text {ef }} \pm 0.06$ & $24.4^{\mathrm{e}} \pm 0.8$ \\
\hline \multirow{11}{*}{ Papain } & 1 & 60 & 1 & $36.1^{\mathrm{a}} \pm 0.1$ & $4.29^{b} \pm 0.11$ & $1.74^{\mathrm{c}} \pm 0.89$ & $6.81^{\text {ef }} \pm 0.47$ & $0.14^{\mathrm{a}} \pm 0.00$ & $46.2^{\mathrm{h}} \pm 1.5$ \\
\hline & 2 & 360 & 1 & $37.1^{b} \pm 0.1$ & $5.41^{\mathrm{e}} \pm 0.09$ & $1.60^{\mathrm{bc}} \pm 1.25$ & $8.27^{\text {efg }} \pm 1.10$ & $0.15^{b} \pm 0.01$ & $29.4^{\mathrm{f}} \pm 0.4$ \\
\hline & 3 & 60 & 5 & $38.8^{\mathrm{e}} \pm 0.1$ & $3.79^{b} \pm 0.70$ & $1.30^{\mathrm{ab}} \pm 0.57$ & $3.42^{b} \pm 0.16$ & $0.16^{\mathrm{c}} \pm 0.07$ & $31.8^{g} \pm 0.1$ \\
\hline & 4 & 360 & 5 & $38.7^{\mathrm{d}} \pm 0.1$ & $7.36^{\mathrm{ij}} \pm 0.40$ & $0.89^{a} \pm 0.26$ & $5.12^{\mathrm{c}} \pm 0.77$ & $0.16^{\mathrm{c}} \pm 0.01$ & $24.2^{\mathrm{d}} \pm 0.7$ \\
\hline & 5 & 60 & 3 & $39.9^{\mathrm{fg}} \pm 0.0$ & $2.70^{a} \pm 0.92$ & $0.87^{\mathrm{a}} \pm 0.24$ & $2.65^{a} \pm 0.01$ & $0.13^{\mathrm{a}} \pm 0.01$ & $28.4^{\mathrm{e}} \pm 0.1$ \\
\hline & 6 & 360 & 3 & $40.4^{g} \pm 0.2$ & $6.63^{\mathrm{hi}} \pm 0.44$ & $1.79^{\mathrm{cd}} \pm 0.88$ & $5.53^{\mathrm{d}} \pm 0.08$ & $0.20^{\mathrm{e}} \pm 0.02$ & $18.5^{\mathrm{ab}} \pm 0.5$ \\
\hline & 7 & 210 & 1 & $42.7^{\mathrm{h}} \pm 0.1$ & $5.50^{\text {ef }} \pm 0.75$ & $1.40^{\mathrm{b}} \pm 0.20$ & $5.28^{\mathrm{cd}} \pm 0.29$ & $0.17^{\mathrm{d}} \pm 0.02$ & $32.0^{g} \pm 1.9$ \\
\hline & 8 & 210 & 5 & $37.8^{c} \pm 0.1$ & $7.91^{\mathrm{j}} \pm 0.16$ & $1.95^{\mathrm{d}} \pm 1.30$ & $5.03^{c} \pm 0.25$ & $0.20^{\mathrm{e}} \pm 0.02$ & $22.5^{c} \pm 1.0$ \\
\hline & 9 & 210 & 3 & $39.8^{\mathrm{fg}} \pm 0.1$ & $6.12^{\mathrm{fg}} \pm 0.45$ & $2.81^{\mathrm{e}} \pm 0.89$ & $6.80^{\text {ef }} \pm 0.46$ & $0.17^{\mathrm{d}} \pm 0.01$ & $17.5^{\mathrm{a}} \pm 0.9$ \\
\hline & 10 & 210 & 3 & $37.9^{c} \pm 0.1$ & $6.25^{\mathrm{gh}} \pm 0.23$ & $2.94^{\mathrm{f}} \pm 0.41$ & $6.70^{\text {ef }} \pm 0.40$ & $0.17^{\mathrm{d}} \pm 0.02$ & $19.2^{b} \pm 1.5$ \\
\hline & 11 & 210 & 3 & $39.6^{\mathrm{f}} \pm 0.2$ & $7.05^{\mathrm{i}} \pm 0.35$ & $1.99^{\mathrm{d}} \pm 0.32$ & $6.67^{\mathrm{e}} \pm 0.57$ & $0.16^{c} \pm 0.01$ & $19.5^{b} \pm 0.2$ \\
\hline
\end{tabular}

Note: Mean $\pm \mathrm{SD}, \mathrm{X}_{1}$ : hydrolysis time $(\mathrm{min}), \mathrm{X}_{2}$ : enzyme concentration (\%); different letters in the same column of each enzyme show significant differences $(p \leq 0.05)$. 


\subsection{The Degree of Hydrolysis (DH) Analysis}

The DH of the jellyfish hydrolysate solution after hydrolysis was determined according to the method described by Mongkonkamthorn et al. [19]. The $125 \mu \mathrm{L}$ sample was diluted with $2 \mathrm{~mL} \mathrm{Na}_{3} \mathrm{PO}_{4}$ buffer ( $\mathrm{pH} 8.2$ ), and $1 \mathrm{~mL}$ TNBS solution $(0.01 \%$ prepared with $0.2125 \mathrm{M}$ phosphate buffer $\mathrm{pH}$ 8.2) was added. The mixture was shaken and kept in the dark at $50{ }^{\circ} \mathrm{C}$ for $30 \mathrm{~min}$. After that, $2 \mathrm{~mL}$ of $0.1 \mathrm{M} \mathrm{Na}_{2} \mathrm{SO}_{3}$ was added into the mixture to terminate the activity, and the mixture was cooled at $25-27^{\circ} \mathrm{C}$ for $15 \mathrm{~min}$, and the absorbance of the mixture was measured at $420 \mathrm{~nm}$ using a microplate reader (Varioskan ${ }^{\mathrm{TM}}$ LUX, Thermo Scientific $^{\mathrm{TM}}$, Waltham, MA, USA). The $\alpha$-amino group was estimated in terms of 2-Amino4-methylpentanoic acid (L-leucine) (Sigma-Aldrich, St. Louis, MO, USA). The following equation was used to determine the $\mathrm{DH}(1)$.

$$
\mathrm{DH}(\%)=\left[\left(\mathrm{L}_{\mathrm{H}}-\mathrm{L}_{0}\right) /\left(\mathrm{L}_{\max }-\mathrm{L}_{0}\right)\right] \times 100
$$

where $\mathrm{L}_{\mathrm{H}}$ is the amount of Leu equivalence obtained from jellyfish hydrolysates. $\mathrm{L}_{0}$ is the amount of Leu equivalence in enzymatic hydrolysate at the initial time. $\mathrm{L}_{\max }$ is the total amount of Leu equivalence in the initial enzymatic hydrolysate taken after hydrolysis in $6 \mathrm{M}$ hydrochloric acid at $100^{\circ} \mathrm{C}$ for $12 \mathrm{~h}$.

\subsection{DPPH Radical Scavenging Activity}

The scavenging activity of the DPPH radical was determined using the modified method of Ahn et al. [23]. The $100 \mu \mathrm{L}$ sample was added $100 \mu \mathrm{L}$ of DPPH solution $(0.1 \mathrm{mM}$ in $70 \%$ ethanol), and the mixture was kept in the dark at $25-27^{\circ} \mathrm{C}$ for $30 \mathrm{~min}$. Distilled water was used as the control and as a substitute sample. An absorbance was obtained at $517 \mathrm{~nm}$ using the microplate reader. The scavenging activity was expressed using Equation (2):

$$
\text { Scavenging activity }(\%)=\left[\left(\mathrm{A}_{\text {control }}-\mathrm{A}_{\text {sample }}\right) / \mathrm{A}_{\text {control }}\right] \times 100
$$

$\mathrm{A}_{\text {control }}$ is the absorbance of the DPPH solution. $\mathrm{A}_{\text {sample }}$ is the absorbance of the sample mixed with DPPH. The activity was presented as $\mathrm{IC}_{50}$ (sample concentration required to inhibit $50 \%$ of initial DPPH concentration). The $\mathrm{IC}_{50}$ value was estimated from the linear regression graph to optimize the process and $\mu \mathrm{mol}$ Trolox equivalents (TE)/g sample for the tested fractions.

\subsection{ABTS Radical Scavenging Activity}

The inhibition activity of the ABTS radical was determined in accordance with the method provided by Ahn et al. [23]. An ABTS solution (7 mM ABTS and $2.45 \mathrm{mM} \mathrm{K}_{2} \mathrm{~S}_{2} \mathrm{O}_{8}$ were mixed together in a 1:1 $(\mathrm{v} / \mathrm{v})$ ratio) was prepared and allowed to activate in the dark for $16-18 \mathrm{~h}$ at $4{ }^{\circ} \mathrm{C}$. Then, it was diluted with $70 \%$ ethanol to acquire an ABTS working solution (absorbance of $0.7 \pm 0.05$ at $734 \mathrm{~nm}$ ). The $100 \mu \mathrm{L}$ of the reaction mixture and $1.9 \mathrm{~mL}$ of the ABTS working solution was mixed and kept in the dark at $25-27^{\circ} \mathrm{C}$ for $8 \mathrm{~min}$. The resultant solution was obtained at $734 \mathrm{~nm}$. The radical scavenging activity ABTS, and the $\mathrm{IC}_{50}$ value were calculated in a similar manner as in the DPPH analysis in order to optimize process and the $\mu \mathrm{mol}$ Trolox equivalents (TE)/g sample for the tested fractions.

\subsection{Ferric Reducing Antioxidant Power (FRAP) Value}

The FRAP value was measured following the method of Wangtueai et al. [24]. A fresh FRAP solution was produced by mixing of $20 \mathrm{mM} \mathrm{FeCl}_{3}$ and $6 \mathrm{H}_{2} \mathrm{O}$ in deionized water, $10 \mathrm{mM}$ TPTZ solution in $40 \mathrm{mM} \mathrm{HCl}$, and $300 \mathrm{mM}$ acetate buffer (pH 3.6) at ratio of 1:1:10 (v:v:v). The FRAP solution was kept in a water bat at $37{ }^{\circ} \mathrm{C}$ for $30 \mathrm{~min}$. An amount of $150 \mu \mathrm{L}$ of the sample was mixed with $2.85 \mathrm{~mL}$ FRAP solution and was reacted for in the dark $30 \mathrm{~min}$. The absorbance of the resultant solution was obtained at $593 \mathrm{~nm}$. The FRAP values were expressed in $\mathrm{mmol} \mathrm{FeSO}_{4} / \mathrm{g}$ sample. Additional dilutions were carried out if the FRAP value was at a higher range in the linear standard curve. 


\subsection{Tyrosianse Inhibitory Activity}

The tyrosinase inhibition activity of jellyfish hydrolysate was measured according to a slightly modified version of the method discussed in Chan et al. [25]. A solution comprising $3.2 \mathrm{mM}$ L-DOPA in $50 \mathrm{mM}$ phosphate buffer ( $\mathrm{pH}$ 6.8) was prepared. This reaction was generated in a multi-well plate. An amount of $10 \mu \mathrm{L}$ of various concentrations of JFH was diluted with $40 \mu \mathrm{L}$ of $50 \mathrm{mM} \mathrm{K}_{3} \mathrm{PO}_{4}$ buffer (pH 6.8) and $70 \mu \mathrm{L}$ of tyrosinase $(150$ units $/ \mathrm{mL}$ activity), and the mixture was allowed to react for $10 \mathrm{~min}$. Then, $80 \mu \mathrm{L} 3.2 \mathrm{mM} \mathrm{L-DOPA}$ was added to each well and incubated for another for $10 \mathrm{~min}$. The absorbance of the resultant solution was measured at $475 \mathrm{~nm}$ using a multi-well plate reader. Kojic acid was used to as a positive control. The inhibitory activity of tyrosinase was expressed following Equation (3):

Tyrosinase inhibitory activity $(\%)=\left\{\left[\mathrm{A}_{\text {control }}-\left(\mathrm{A}_{\text {sample }}-\mathrm{A}_{\text {colour }}\right)\right] /\left(\mathrm{A}_{\text {control }}-\mathrm{A}_{\text {blank }}\right)\right\} \times 100$

where $A_{\text {blank }}$ is the absorbance of deionized water. $A_{\text {colour }}$ is an absorbance of a mixture comprising the sample with phosphate buffer. $A_{\text {control }}$ is the absorbance of a mixture comprising buffer, tyrosinase, and L-DOPA without sample. $\mathrm{A}_{\text {sample }}$ is the absorbance of solution resulting from the reaction.

The $\mathrm{IC}_{50}$ values were calculated in a similar manner as the $\mathrm{DPPH}$ analysis.

\subsection{Amino Acid Analysis}

The Amino acid composition of the jellyfish hydrolysate with flavourzyme hydrolysis (JFFH) powder was analyzed using HPLC (HP 1260, Fluorescence Detector, Agilent Technologies, Waldbronn, Germany) according to Herbert et al. [26]. The standard mixture of amino acids (Sigma-Aldrich, St. Louis, MO, USA) was applied for both identification and quantitation. The amino acid content was expressed in $\mathrm{g}$ amino acid/100 $\mathrm{g}$ of JFFH.

\subsection{In Vitro Cytotoxicity Determination}

Human keratinocytes cells (HaCaT cell line) were purchased from XL Biotec Co., Ltd. (Bangkok, Thailand). HaCaT cells were plated in DMEM containing 10\% FBS, $2 \mathrm{mM}$ glutamine, and $1 \%$ penicillin $(100 \mathrm{U} / \mathrm{mL})$ in a $5 \% \mathrm{CO}_{2}$ atmosphere at $37{ }^{\circ} \mathrm{C}$. The effects of jellyfish hydrolysate on $\mathrm{HaCaT}$ cell cytotoxicity and cell viability were measured using the MTT value determined by Pastorino et al. [27]. Briefly, HaCaT cells were seeded on a 96-well culture plate at $1 \times 10^{4}$ cell/well $(100 \mu \mathrm{L})$ and were incubated $12 \mathrm{~h}$ to obtain cells that were attached to the substratum. The cells were treated with JFFH, JFAH, and JFPH at a various concentration $(312.5,625,1250,2500$, and $5000 \mu \mathrm{g} / \mathrm{mL})$, and some were left untreated (control) for $24 \mathrm{~h}$ at $37^{\circ} \mathrm{C}$. After incubation, $15 \mu \mathrm{L}$ of the MTT solution $(5 \mathrm{mg} / \mathrm{mL}$ in PBS) was added to each well. After subsequent incubation for $4 \mathrm{~h}$, the purple-colored precipitates were obvious. The supernatant was removed, and the formazan precipitates were solubilized with the addition of $100 \mu \mathrm{L}$ DMSO per well. Then, after $10 \mathrm{~min}$ of incubation, absorbances were obtained at 540 and $630 \mathrm{~nm}$ using a scanning multi-well microplate reader (SpectraMax i3x, Molecular Devices, CA, USA). The cell viability was expressed using Equation (4).

$$
\% \text { Cell viability }=[(\mathrm{OD} \text { of treated }) /(\mathrm{OD} \text { of control })] \times 100
$$

where $\mathrm{OD}_{\text {treated }}$ is $\mathrm{OD}$ treated $540-\mathrm{OD}_{\text {treated }} 630, \mathrm{OD}_{\text {control }}$ is $\mathrm{OD}_{\text {control }} 540-\mathrm{OD}_{\text {control }} 630$.

\subsection{Isolation of Antioxidant and Anti-Tyrosinase Peptides from Jellyfish Hydrolysate \\ 2.12.1. Fractionation of Jellyfish Hydrolysate by Ultrafiltration}

The JFFH were fractionated using an Amicon ${ }^{\circledR}$ stirred cell (Merck KGaA, Darmstadt, Germany) with an ultrafiltration membrane bioreactor system with a range of molecular weight cut-offs: 10,3 , and $1 \mathrm{kDa}$. Sample (10 g) was dissolved in deionized water $(200 \mathrm{~mL})$ $(5 \% w: v)$ and fractionated using a nominal series of MWCO membranes: 1, 3 and $10 \mathrm{kDa}$. 
Four peptide fractions (fraction I (>10 kDa), fraction II (3-10 kDa), fraction III (1-3 kDa) and fraction IV $(<1 \mathrm{kDa}))$ were collected and freeze dried. The JFFH fractions were analyzed to determine their antioxidant and tyrosinase inhibitory activity.

\subsubsection{Gel Filtration Chromatography}

The JFFH fraction with the highest anti-tyrosinase and highest antioxidant activity obtained from the ultrafiltration membrane was further separated using a gel filtration column $(2.6 \times 70 \mathrm{~cm})$ with a Sephadex G-25 (GE Healthcare Bio-Science AB, Uppsala, Sweden). The low-pressure chromatography system (BioLogic LP system, Bio-Rad, Hercules, CA, USA) with a connected fraction collector (Biofrac Fraction Collector, Bio-Rad Laboratories) was used. In brief, $100 \mathrm{mg}$ sample was dissolved in $2 \mathrm{~mL}$ distilled water, filtered through a $0.45 \mu \mathrm{m}$ syringe filter PTFE (F13-PT045, Chrom Tech, MN, USA), injected onto a column, eluted with distilled water at a $0.5 \mathrm{~mL} / \mathrm{min}$ flow rate, and collected with $3 \mathrm{~mL}$ eluted solution/fraction. The absorbances of the fractions were determined at 220 and $280 \mathrm{~nm}$, as were the DPPH and ABTS radical scavenging activity, FRAP value, and tyrosinase inhibitory activity. The void volume of the column was measured using blue dextran (2000 kDa). Molecular-weight (MW) protein standards (tyrosine (181 Da), Gly-Try (238 Da), vitamin B12 (1356 Da), and insulin chain B (3496 Da)) were used for peptide MW estimation.

\subsection{Experimental Design}

The optimum conditions for jellyfish hydrolysis were determined using a response surface methodology with a face-centered composite design (two-factor three-levels). The independent variable effect (the hydrolysis time $\left(X_{1}, 60-360 \mathrm{~min}\right)$ and the enzyme concentration $\left(\mathrm{X}_{2}, 1-5 \%\right)$ ) on the $\mathrm{DH}$, yield, $\mathrm{IC}_{50}$ value of the DPPH and ABTS radical scavenging and tyrosinase inhibition activity $(\mathrm{mg} / \mathrm{mL})$, and FRAP value $\left(\mathrm{mmol} \mathrm{FeSO}_{4} / \mathrm{g}\right.$ sample) were evaluated. The experiments with each enzyme consisted of 11 treatments (8 incomplete factorials and 3 replicated central points), as shown in Table 1. The design of the experimental, analysis and response surface plots were carried out using Design Expert software (version 11, Stat-Ease, Inc., Minneapolis, MN, USA). A full quadratic model for each response was obtained and expressed with real variables using following Equation (5):

$$
Y i=\beta_{0}+\beta_{1 X 1}+\beta_{2} x_{2}+\beta_{11} x_{1}^{2}+\beta_{22} x_{2}^{2}+\beta_{12} x_{1} x_{2}+\varepsilon
$$

where $Y_{i}$ is the response variables, and $x_{1}$ and $x_{2}$ are the independent variables, whereas $\varepsilon$ represents the random error, and $\beta_{0}, \beta_{1}, \beta_{2}, \beta_{11}, \beta_{22}$, and $\beta_{12}$ are the coefficients for the constant, linear, quadratic, and interaction terms.

One-way analysis of variance (ANOVA) was carried out using SPSS Statistical software version 17 (SPSS Inc., Chicago, IL, USA), and the means comparison $(p \leq 0.05)$ was conducted using Duncan's new multiple range test (DMRT).

\section{Results and Discussion}

\subsection{Chemical Composition of Jellyfish}

The Chemical composition of the desalted jellyfish (rehydrated jellyfish) was $82.6 \%$ moisture, $13.1 \%$ crude protein, $4.1 \%$ ash, and $0.6 \%$ fat content. A previous report by Rodsuwan et al. [11] showed the proximate compositions of dried desalted jellyfish as being $70 \%$ protein, $10 \%$ moisture, $9 \%$ fat, and $<1 \%$ ash content. The composition of the jellyfish tissue was largely determined based on the bodies of water in which these invertebrates were discovered. In dried Stomolophus meleagris, Cotylorhiza tuberculate, Rhizostoma pulmo, and Lobonema smithii, protein and ash were the predominant constituents, while fatty acids were more prevalent in zooxanthellate jellyfish [28-30]. 


\subsection{Response Surface Models}

The results of the hydrolysis time $\left(\mathrm{X}_{1}\right)$ and alcalase, flavourzyme, and papain concentration $\left(X_{2}\right)$ on the jellyfish hydrolysate are shown in Table 1. A comprehensive response surface model was fitted using regression analysis. The regression coefficients for the full-2nd-order response surface models are shown in Table 2. Most of the models for each enzyme were significant $(p \leq 0.05)$ terms. The coefficients of determination $\left(R^{2}\right)$ were $0.78-0.99$. Furthermore, the lack of fit for the models were not significant $(p>0.05)$, indicating relationships among the selected parameters as well as a high degree of confidence for explaining the effect of the variables in the observed data [31].

Table 2. Full quadratic model of jellyfish hydrolysis using alcalase, flavourzyme, and papain.

\begin{tabular}{|c|c|c|c|c|}
\hline Enzyme & Responses & Quadratic Polynomial Model & $R^{2}$ & $p$-Value \\
\hline \multirow{6}{*}{ Alcalase } & $\mathrm{DPPH}\left(\mathrm{IC}_{50}\right)(\mathrm{mg} / \mathrm{mL})$ & \multirow{6}{*}{$\begin{array}{c}\mathrm{Y}_{1}=-0.429-0.004 \mathrm{X}_{1}+1.912 \mathrm{X}_{2}+0.001 \mathrm{X}_{1} \mathrm{X}_{2}+0.00001 \mathrm{X}_{1}^{2}-0.335 \mathrm{X}_{2}^{2} \\
\mathrm{Y}_{2}=3.74+0.019 \mathrm{X}_{1}-0.172 \mathrm{X}_{2}-0.0001 \mathrm{X}_{1}^{2}-0.010 \mathrm{X}_{2}^{2}+0.001 \mathrm{X}_{1} \mathrm{X}_{2} \\
\mathrm{Y}_{3}=0.316-0.001 \mathrm{X}_{1}-0.065 \mathrm{X}_{2}-0.00003 \mathrm{X}_{1} \mathrm{X}_{2}+0.000001 \mathrm{X}_{1}^{2}+ \\
0.010 \mathrm{X}_{2}^{2} \\
\mathrm{Y}_{4}=0.93+0.028 \mathrm{X}_{1}+13.9 \mathrm{X}_{2}-0.0001 \mathrm{X}_{1}^{2}-1.69 \mathrm{X}_{2}^{2}-0.001 \mathrm{X}_{1} \mathrm{X}_{2} \\
\mathrm{Y}_{5}=-0.071+0.004 \mathrm{X}_{1}+1.09 \mathrm{X}_{2}-0.00001 \mathrm{X}_{1}^{2}-0.145 \mathrm{X}_{2}^{2}+0.001 \mathrm{X}_{1} \mathrm{X}_{2} \\
\mathrm{Y}_{6}=19.6+0.218 \mathrm{X}_{1}-9.14 \mathrm{X}_{2}-0.001 \mathrm{X}_{1}^{2}+1.53 \mathrm{X}_{2}^{2}-0.01 \mathrm{X}_{1} \mathrm{X}_{2}\end{array}$} & 0.8393 & 0.0469 \\
\hline & $\mathrm{ABTS}\left(\mathrm{IC}_{50}\right)(\mathrm{mg} / \mathrm{mL})$ & & 0.8377 & 0.0479 \\
\hline & FRAP $\left(\mathrm{mmol} \mathrm{FeSO}_{4} / \mathrm{g}\right)$ & & 0.9729 & 0.0006 \\
\hline & $\% \mathrm{DH}$ & & 0.8282 & 0.0547 \\
\hline & $\%$ Yield & & 0.886 & 0.021 \\
\hline & Tyrosinase $\left(\mathrm{IC}_{50}\right)(\mathrm{mg} / \mathrm{mL})$ & & 0.8433 & 0.0442 \\
\hline \multirow{6}{*}{ Flavourzyme } & $\mathrm{DPPH}\left(\mathrm{IC}_{50}\right)(\mathrm{mg} / \mathrm{mL})$ & $Y_{1}=0.29+0.028 X_{1}-0.287 X_{2}-0.0001 X_{1}^{2}+0.03 X_{2}^{2}+0.002 X_{1} X_{2}$ & 0.9367 & 0.0051 \\
\hline & ABTS $\left(\mathrm{IC}_{50}\right)(\mathrm{mg})$ & $\mathrm{Y}_{2}=12.9-0.09 \mathrm{X}_{1}+1.67 \mathrm{X}_{2}+0.0003 \mathrm{X}_{1}^{2}-0.37 \mathrm{X}_{2}^{2}-0.002 \mathrm{X}_{1} \mathrm{X}_{2}{ }_{2}$ & 0.8939 & 0.0177 \\
\hline & $\mathrm{FRAP}\left(\mathrm{mmol} \mathrm{FeSO}_{4} / \mathrm{g}\right)$ & $\mathrm{Y}_{3}=0.15+0.04 \mathrm{X}_{1}+0.05 \mathrm{X}_{2}+0.003 \mathrm{X}_{1}^{2}+0.02 \mathrm{X}_{2}^{2}+0.01 \mathrm{X}_{1} \mathrm{X}_{2}$ & 0.9913 & $<0.0001$ \\
\hline & $\% \mathrm{DH}$ & $\mathrm{Y}_{4}=18.0+0.12 \mathrm{X}_{1}+4.60 \mathrm{X}_{2}-0.002 \mathrm{X}_{1}^{2}-0.16 \mathrm{X}_{2}^{2}-0.01 \mathrm{X}_{1} \mathrm{X}_{2}$ & 0.9091 & 0.0122 \\
\hline & $\%$ Yield & $Y_{5}=0.05+0.02 X_{1}+0.45 X_{2}-0.0001 X_{1}^{2}+0.01 X_{2}^{2}+0.01 X_{1} X_{2}$ & 0.9801 & 0.0003 \\
\hline & Tyrosinase $\left(\mathrm{IC}_{50}\right)(\mathrm{mg} / \mathrm{mL})$ & $\mathrm{Y}_{6}=59.6-0.16 \mathrm{X}_{1}-7.39 \mathrm{X}_{2}+0.002 \mathrm{X}_{1}^{2}+0.26 \mathrm{X}_{2}^{2}+0.014 \mathrm{X}_{1} \mathrm{X}_{2}$ & 0.9375 & 0.005 \\
\hline \multirow{6}{*}{ Papain } & $\mathrm{DPPH}\left(\mathrm{IC}_{50}\right)(\mathrm{mg})$ & $Y_{1}=3.98-0.01 X_{1}-0.19 X_{2}+0.000002 X_{1}^{2}-0.05 X_{2}^{2}+0.001 X_{1} X_{2}$ & 0.9341 & 0.0056 \\
\hline & $\operatorname{ABTS}\left(\mathrm{IC}_{50}\right)(\mathrm{mg} / \mathrm{mL})$ & $\mathrm{Y}_{2}=7.80+0.01 \mathrm{X}_{1}-0.17 \mathrm{X}_{2}-0.00002 \mathrm{X}_{1}^{2}-0.013 \mathrm{X}_{2}^{2}-0.001 \mathrm{X}_{1} \mathrm{X}_{2}$ & 0.9874 & $<0.0001$ \\
\hline & FRAP (mmol $\left.\mathrm{FeSO}_{4} / \mathrm{g}\right)$ & $Y_{3}=0.13+0.00002 X_{1}-0.01 X_{2}+0.0000003 X_{1}^{2}+0.01 X_{2}^{2}-0.00001 X_{1} X_{2}$ & 0.9253 & 0.0076 \\
\hline & $\% \mathrm{DH}$ & $\mathrm{Y}_{4}=40.1-0.01 \mathrm{X}_{1}-0.87 \mathrm{X}_{2}+0.00002 \mathrm{X}_{1}^{2}+0.07 \mathrm{X}_{2}^{2}+0.002 \mathrm{X}_{1} \mathrm{X}_{2}$ & 0.7832 & 0.0924 \\
\hline & $\%$ Yield & $\mathrm{Y}_{5}=5.99+0.01 \mathrm{X}_{1}-0.55 \mathrm{X}_{2}-0.00001 \mathrm{X}_{1}^{2}+0.05 \mathrm{X}_{2}^{2}+0.002 \mathrm{X}_{1} \mathrm{X}_{2}$ & 0.9388 & 0.0047 \\
\hline & Tyrosinase $\left(\mathrm{IC}_{50}\right)(\mathrm{mg} / \mathrm{mL})$ & $\mathrm{Y}_{6}=39.2-0.04 \mathrm{X}_{1}-4.01 \mathrm{X}_{2}+0.0001 \mathrm{X}_{1}^{2}+0.73 \mathrm{X}_{2}^{2}-0.01 \mathrm{X}_{1} \mathrm{X}_{2}$ & 0.8818 & 0.0229 \\
\hline
\end{tabular}

Note: Mean $\pm \mathrm{SD}, \mathrm{X}_{1}$ : hydrolysis time $(\mathrm{min}), \mathrm{X}_{2}$ : enzyme concentration $(\%)$

The plots of the response surface that were used to predict the effects of the hydrolysis time and concentration of alcalase, flavourzyme, or papain on the responses are shown in three-dimensional plots in Figure 1. For flavourzyme, both the hydrolysis time and enzyme concentration had the great effect on yield (Figure 1A1-A3), while the enzyme concentration and hydrolysis time and that most significant effect on alcalase and papain, respectively (Figure 2). Both independent factors were found to impact on yield in papain (Figure 3). Protein hydrolysate yield increased as the hydrolysis time and enzyme concentration increased. This might be due to the higher amount of peptide cleavage in the native protein during enzyme hydrolysis and the conversion to shorter or longer peptides, resulting in a higher hydrolysate yield. Similar results were also obtained in previous studies for eel protein hydrolysate [32] and herring muscle [33]. Various factors may have influenced hydrolysate yield, but type of enzyme used for hydrolysis had the greatest effect on the yield and properties [34]. This study ranks the hydrolysis yields of alcalase, flavourzyme, and papain, as shown in Table 1. Flavourzyme is a combination of endo- and exopeptidases that can produce both free amino acids and peptides, while alcalase and papain are endopeptidases that can hydrolyze protein with a high degree of specificity, particularly peptide bonds, and have a preference for uncharged residues $[35,36]$. 


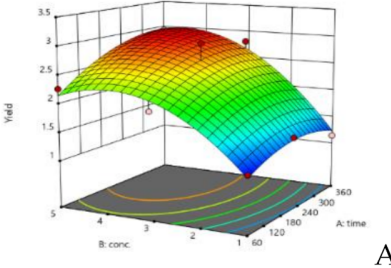

A1

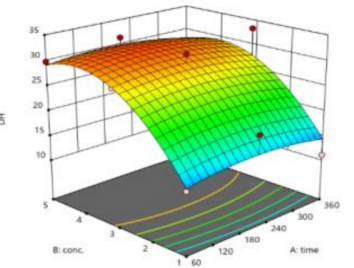

B1

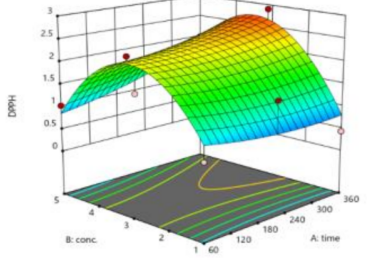

C1

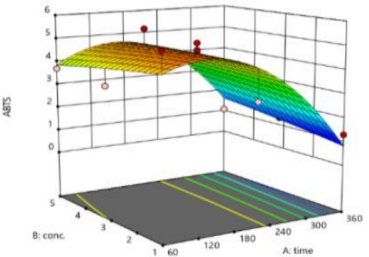

D1

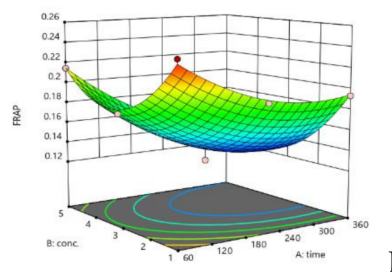

E1

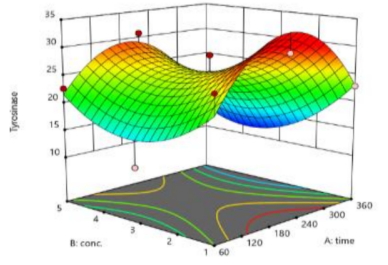

문

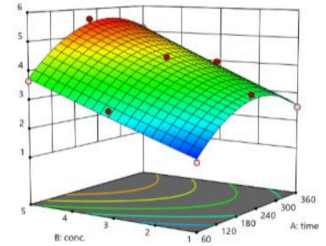

A2

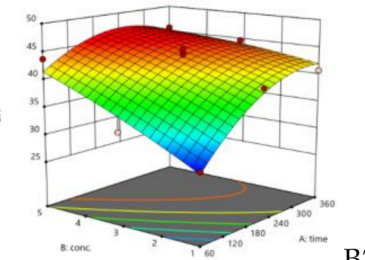

B2

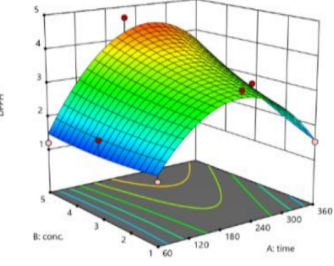

C2

星

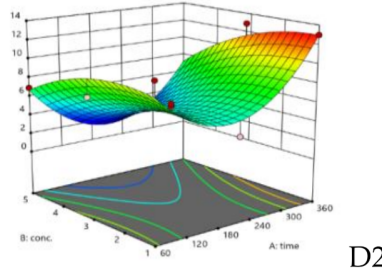

蛋

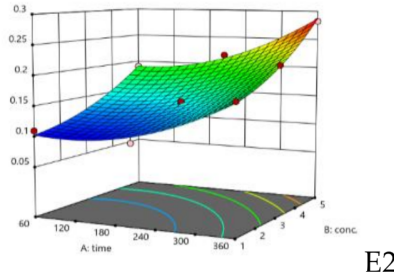

E2

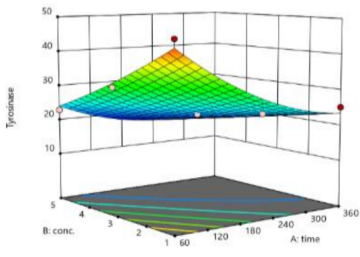

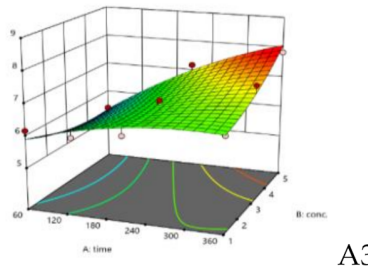

A3

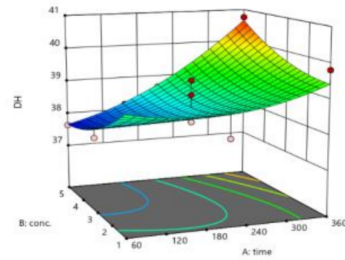

B3

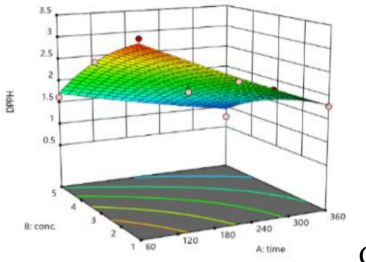

C3

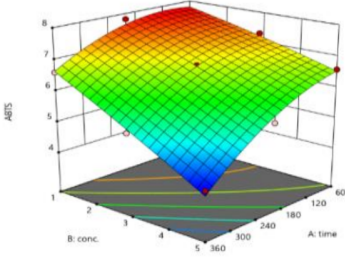

D3
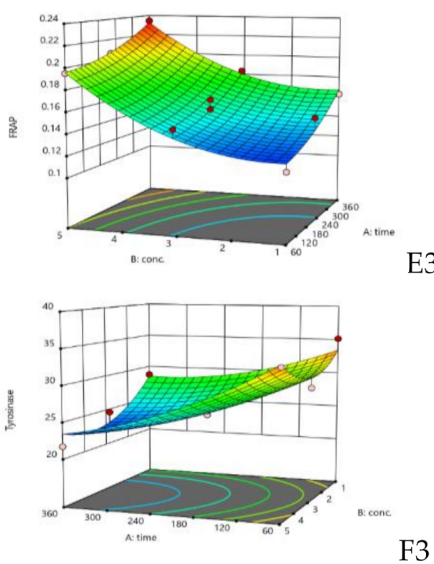

Figure 1. Response surface plots for $\mathrm{DH}$, yield, $\mathrm{IC}_{50}$ of $\mathrm{DPPH}$ and $\mathrm{ABTS}$ radical scavenging, and tyrosinase inhibitory activity: and FRAP value using alcalase (A1-F1), flavourzyme (A2-F2), and papain (A3-F3) hydrolysis.

The effects of independent variables on the DH of JFH are shown in Figure 1B1-B3. The hydrolysis time had a significant effect on the DH for flavourzyme and papain, while the enzyme concentration had a significant effect on alcalase and flavourzyme (Figure 2). The DH increased as the enzyme concentration and hydrolysis time increased. The DH of jellyfish hydrolysate in this study was similar to those of previous studies, such as herring beluga viscera [37], tuna dark muscle by-products [17,38], and channel catfish skin [39]. Normally, the DH is higher when the reaction time is longer and increases rapidly at the beginning of a reaction before showing down and stabilizing [40,41]. The DH reflects the percentage of peptide bonds broken down by each protease. This allows the stage where number and size of peptides will have the best activity to be determined [40]. 


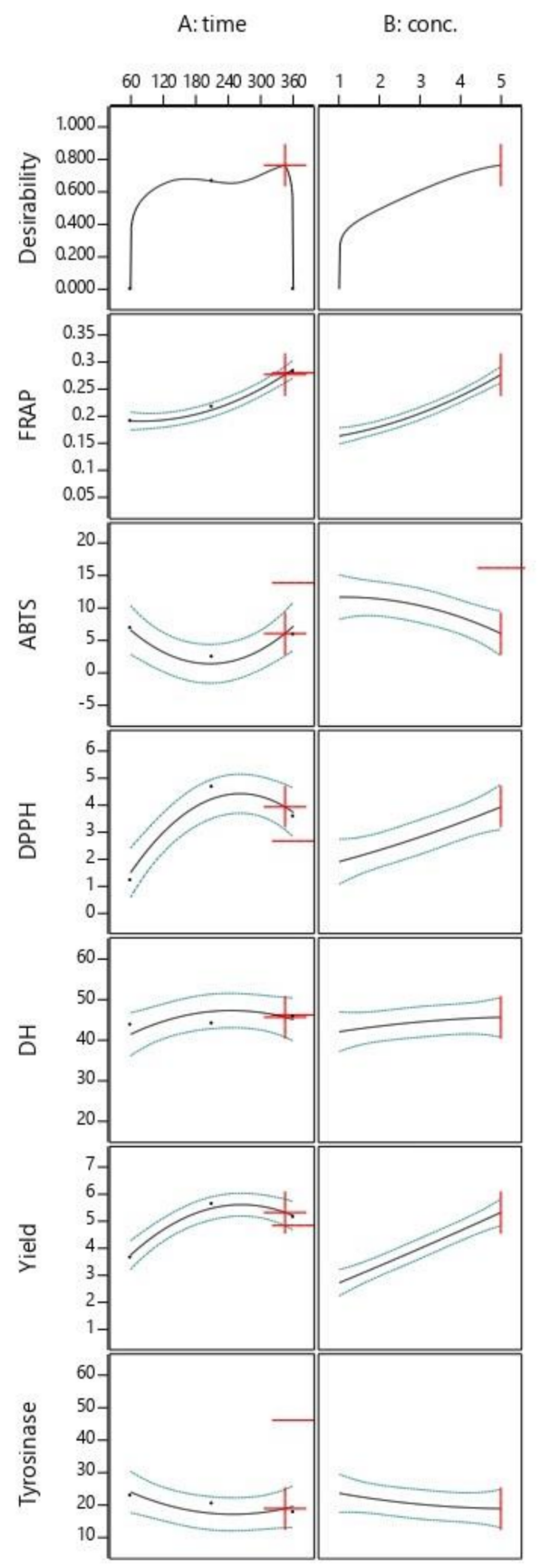

(a)

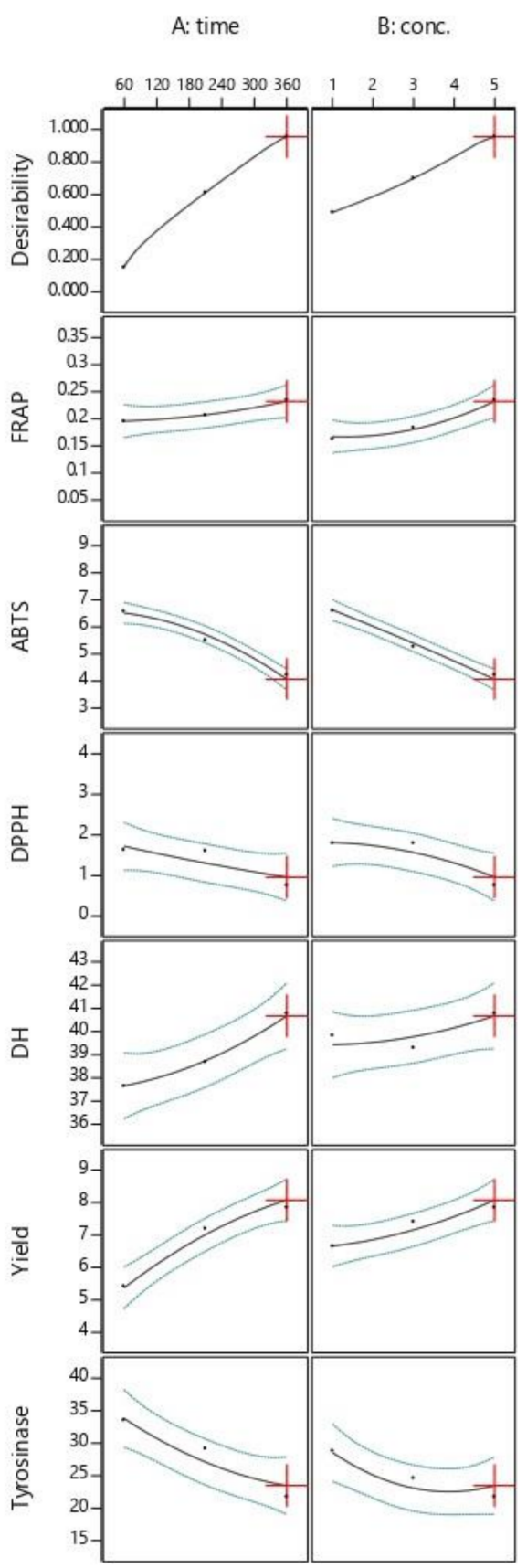

(b)

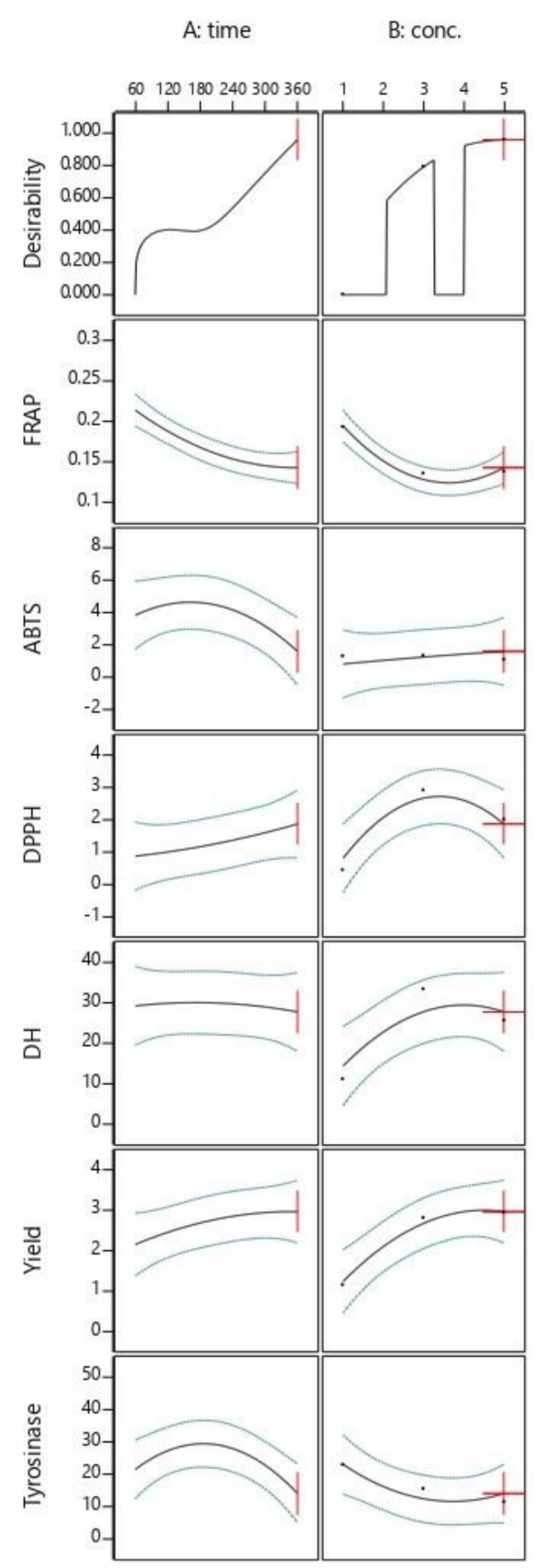

(c)

Figure 2. Plots of the main effects of hydrolysis time $\left(X_{1}\right)$ and enzyme concentration $\left(X_{2}\right)$ on $D H$, yield, DPPH and ABTS radical scavenging, FRAP value, and tyrosinase inhibition activity using alcalase (a), flavourzyme (b) and papain (c) hydrolysis. 


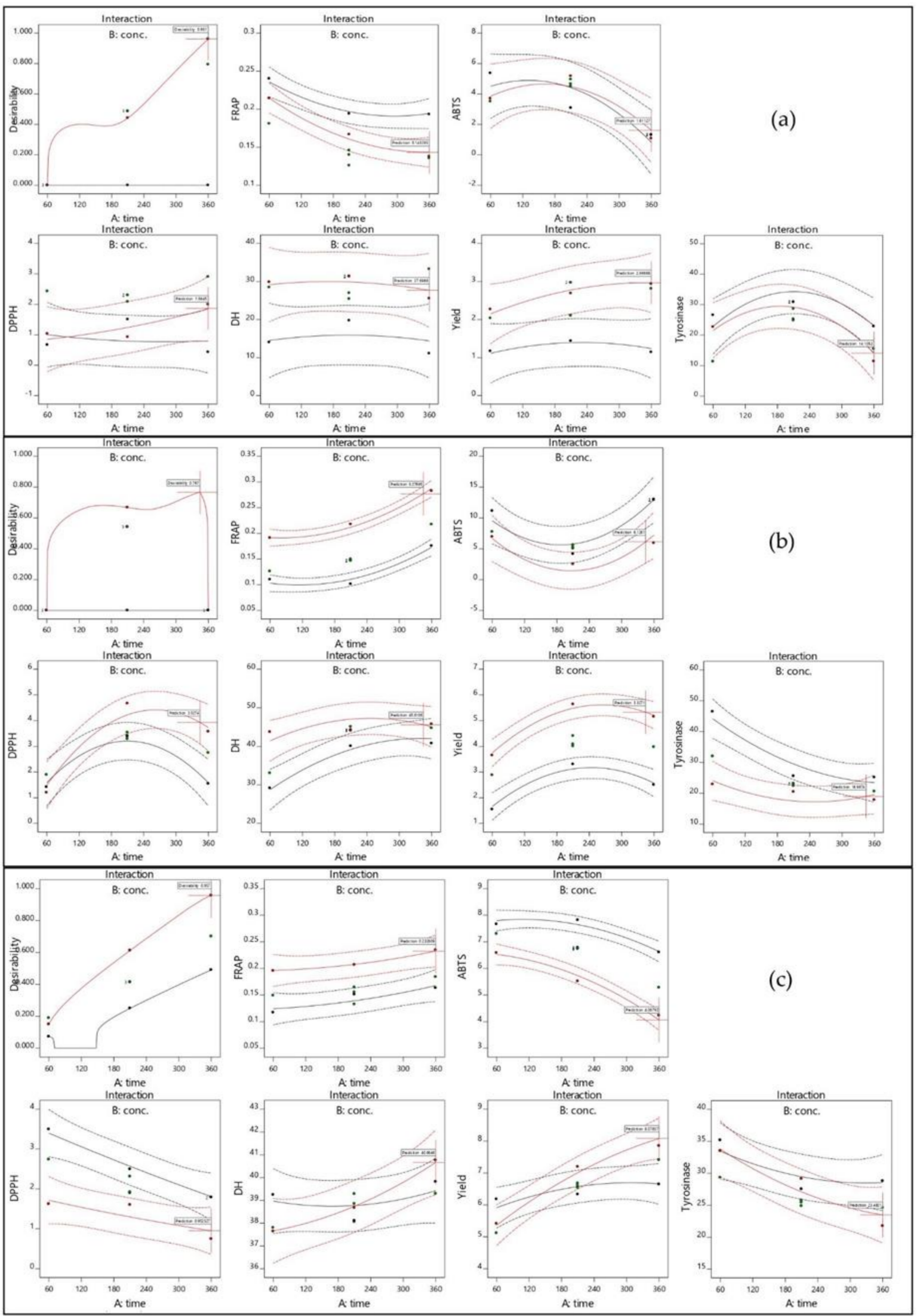

Figure 3. Plot of the interaction effect for hydrolysis time $\left(X_{1}\right)$ and enzyme concentration $\left(X_{2}\right)$ on $\mathrm{DH}$, yield, DPPH and ABTS radical scavenging, FRAP value, and tyrosinase inhibition activity using alcalase (a), flavourzyme (b), and papain (c) hydrolysis. 
As shown in Figure 1C1-E3 exhibit the effects of the independent factors on the three responses to antioxidant activity: DPPH, ABTS, and FRAP, respectively. For flavourzyme and papain, the $\mathrm{IC}_{50}$ value of the $\mathrm{DPPH}$ radical scavenging activity was influenced by both independent variables. The duration of hydrolysis and the enzyme concentration demonstrated significant effects on the $\mathrm{IC}_{50}$ value of the ABTS radical scavenging activity of alcalase and flavourzyme hydrolysates, respectively, whereas both independent variables were caused significant effects in papain (Figure 2). However, the interaction between both independent variables affected the DPPH and ABTS for both flavourzyme and papain, respectively (Figure 3). Increasing the enzyme concentration and hydrolysis time increased the $\mathrm{DH}$ and led to good antioxidant activity in the jellyfish hydrolysates. The smaller peptides possessed more metal chelating and radical scavenging capabilities than the larger peptides, as per the results of Saidi et al. [41]. Different enzymes cleaved the peptide bonds at different positions in the protein structure, resulting in varying peptide sequences with various antioxidant activities [42]. Increasing the number of hydrophobic peptides showed a high reaction rate against free radicals [32]. After increasing the DH from 15 to $65 \%$, a goby muscle hydrolysate short peptide with a stronger antioxidant was generated [43].

The effect of the independent variables on the $\mathrm{IC}_{50}$ value of the tyrosinase inhibition activity of jellyfish hydrolysate are shown in Figure 1F1-F3. Both the enzyme concentration and hydrolysis time had a significant effect on flavourzyme, while hydrolysis time significantly affected papain (Figure 2). The interaction effect for both independent variables on the tyrosinase inhibition activity was only in papain (Figure 3). Increased hydrolysis times and greater enzyme concentrations resulted in decreased $\mathrm{IC}_{50}$ values for tyrosinase inhibition activity (indicating strong tyrosinase inhibitory). Tyrosinase is a $\mathrm{Cu}^{2+}$-containing enzyme that plays an important role in melanogenesis and that could be catalyzed by quinones [44]. Therefore, antioxidative substances with the ability to prohibit the oxidative pathway and/or binding to the tyrosinase activity site $\left(\mathrm{Cu}^{2+}\right)$ could inhibit the catalytic reaction of the enzymes. Polar or uncharged amino acid residues such as Ser and Cys are typically found in effective tyrosinase inhibitor peptides [4]. According to the report by Masuda et al. [45], some tyrosinase inhibitors also have strong antioxidant activity.

\subsection{Multiple Response Optimization and Model Validation}

The desirability function of the Design Expert Statistical program was used to optimize the hydrolysis conditions using multiple response optimization. Maximum targets were established for the $\mathrm{DH}$, yield, and FRAP values, whereas minimum goals were set for the $\mathrm{IC}_{50}$ values for DPPH, ABTS radical scavenging, and tyrosinase inhibition activity. Table 3 shows the individual and composite desirability values of each response, assuming that all of the responses were evaluated equally. The results indicated that the optimal conditions for each enzyme were an enzyme concentration of $5 \%$ and hydrolysis times of 360, 345, or $360 \mathrm{~min}$ for alcalase (JFAH), flavourzyme (JFFH), and papain (JFPH), respectively. These optimal conditions were validated to obtain the experimental values. As indicated in Table 3, the predicted values were not substantially different from the experiment values $(p>0.05)$. The results indicated that they were good predictors. Based on the experimental values, some of which show better bioactivity than others, the most effective was JFFH, which was chosen for further research.

\subsection{Amino Acid Profile}

JFFH's amino acid profile presented in Table 4. Gly, Ala, Glx, Alx, and Pro were the most abundant amino acids in JFFH, accounting for around 18, 14, 13, 9, and 9\% of the total amino acid composition, respectively. The hydrophobic amino acids Ala, Tyr, Val, Met, Cys, Ile, Phe, Trp, Leu, and Pro composed 43\% of JFFH, whereas the other $\sim 57 \%$ of JFFH comprised hydrophilic amino acids. The hydrophobic amino acid groups are important for bioactivity, especially in terms of antioxidant and antiproliferative activity of protein hydrolysates [46,47]. As a consequence, JFFH's stronger antioxidant and tyrosinase inhibition activity might be related to its higher hydrophobic amino acid content. According 
to Schurink et al. [4], peptides possessing polar, uncharged amino acid residues, such as Ser and Cys, are similarly effective in inhibiting tyrosinase. The tyrosine-inhibitory activity might be related to a thiol group in a Cys-containing peptide chelating copper ions [48].

Table 3. Optimized hydrolysis conditions and verification model for all responses of jellyfish hydrolysate using alcalase (JFAH), flavourzyme (JFFH), and papain (JFPH) hydrolysis.

\begin{tabular}{|c|c|c|c|c|c|c|c|c|c|}
\hline \multirow[b]{2}{*}{ Enzyme } & \multirow[b]{2}{*}{ Value } & \multicolumn{2}{|c|}{ Factors } & \multicolumn{6}{|c|}{ Responses } \\
\hline & & $\begin{array}{c}X_{1} \\
(\min )\end{array}$ & $X_{2}(\%)$ & $\% \mathrm{DH}$ & \%Yield & $\begin{array}{c}\mathrm{DPPH}\left(\mathrm{IC}_{50}\right) \\
(\mathrm{mg} / \mathrm{mL})\end{array}$ & $\begin{array}{c}\operatorname{ABTS}\left(\mathrm{IC}_{50}\right) \\
(\mathrm{mg} / \mathrm{mL})\end{array}$ & $\begin{array}{c}\text { FRAP }\left(\mathrm{IC}_{50}\right) \\
(\mathrm{mmol} \\
\left.\mathrm{FeSO}_{4} / \mathrm{g}\right)\end{array}$ & $\begin{array}{c}\text { Tyrosinase } \\
\text { Inhibitory } \\
\left(\mathrm{IC}_{50}\right)(\mathrm{mg} / \mathrm{mL})\end{array}$ \\
\hline JFAH & $\begin{array}{l}\text { Predicated value } \\
\text { Experimental value } \\
\text { Composite } \\
\text { desirability }\end{array}$ & 360 & 5 & $\begin{array}{c}27.7 \\
28.2^{\mathrm{a}} \pm 1.1\end{array}$ & $\begin{array}{c}2.97 \\
3.01^{\mathrm{a}} \pm 0.04\end{array}$ & \begin{tabular}{l}
\multicolumn{1}{c}{2.30} \\
$2.5^{\mathrm{c}} \pm 0.1$ \\
0.96
\end{tabular} & $\begin{array}{c}1.61 \\
1.81^{\mathrm{a}} \pm 0.02\end{array}$ & $\begin{array}{c}0.14 \\
0.13^{a} \pm 0.05\end{array}$ & $\begin{array}{c}14.1 \\
14.9^{\mathrm{b}} \pm 0.0\end{array}$ \\
\hline JFFH & $\begin{array}{l}\text { Predicated value } \\
\text { Experimental value } \\
\text { Composite } \\
\text { desirability }\end{array}$ & 345 & 5 & $\begin{array}{c}45.6 \\
47.3^{c} \pm 0.3\end{array}$ & $\begin{array}{c}5.32 \\
6.40^{\mathrm{b}} \pm 0.03\end{array}$ & $\begin{array}{c}0.81 \\
0.73^{a} \pm 0.14 \\
0.96\end{array}$ & $\begin{array}{c}5.40 \\
2.58^{\mathrm{b}} \pm 0.19\end{array}$ & $\begin{array}{c}0.17 \\
0.23^{b} \pm 0.04\end{array}$ & $\begin{array}{c}19.0 \\
14.1^{\mathrm{ab}} \pm 0.1\end{array}$ \\
\hline JFPH & $\begin{array}{c}\text { Predicated value } \\
\text { Experimental value } \\
\text { Composite } \\
\text { desirability }\end{array}$ & 360 & 5 & $\begin{array}{c}40.7 \\
41.8^{b} \pm 0.5\end{array}$ & $\begin{array}{c}7.45 \\
7.21^{\mathrm{bc}} \\
1.05\end{array} \pm$ & $\begin{array}{c}0.95 \\
0.98^{b} \pm 0.04 \\
0.95\end{array}$ & $\begin{array}{c}4.30 \\
4.50^{c} \pm 0.08\end{array}$ & $\begin{array}{c}0.23 \\
0.27^{c} \pm 0.02\end{array}$ & $\begin{array}{c}23.5 \\
24.5^{c} \pm 0.0\end{array}$ \\
\hline
\end{tabular}

Note: Mean $\pm \mathrm{SD}, \mathrm{X}_{1}$ : hydrolysis time $(\mathrm{min}), \mathrm{X}_{2}$ : enzyme concentration (\%); different superscripts in the same experimental values of response show significant differences $(p \leq 0.05)$.

Table 4. Amino acid content in jellyfish hydrolysate using flavourzyme hydrolysis (JFFH).

\begin{tabular}{cc}
\hline Amino Acid & g Amino Acid/100 g of Sample \\
\hline Asn + Asp & 5.00 \\
Gln + Glu & 6.96 \\
Ser & 1.85 \\
Thr & 1.46 \\
His & 0.23 \\
Gly & 9.74 \\
Ala & 4.50 \\
Arg & 3.53 \\
Tyr & 0.60 \\
Val & 1.62 \\
Met & 0.45 \\
Cys & 7.70 \\
Ile & 1.23 \\
Phe & 0.48 \\
Trp & 0.19 \\
Leu & 2.02 \\
Lys & 2.27 \\
Pro & 4.97 \\
Total amino acid & 54.76 \\
\hline
\end{tabular}

\subsection{Effect of Jellyfish Hydrolysate on Cell Viability}

The effect on cell viability of jellyfish hydrolysate was evaluated based on the MTT value in the HaCaT cell lines, as shown in Figure 4. The cell viability was calculated compared to that of $\mathrm{HaCaT}$ that had been cell-cultured without jellyfish hydrolysate (control), reporting an $80 \%$ ( $\mathrm{IC}_{80}$ value) survival rate. This result showed that the cell survival increased when the concentration increased from 0.313 to $0.625 \mathrm{mg} / \mathrm{mL}$ for all hydrolysates and decreased afterwards. The JFPH, JFAH, and JFFH concentrations of $0.313-1.25 \mathrm{mg} / \mathrm{mL}$ resulted in cell viability $>100 \%$ as well as low cytotoxicity and potentially enhanced cell growth. Even at the highest dose $(5 \mathrm{mg} / \mathrm{mL})$, the jellyfish hydrolysate was non-cytotoxic. Domenico et al. [20] reported that the crude aqueous soluble protein (SP) of R. pulmo was able to diminish the cell viability of human epidermal keratinocyte to $60 \%$ when the SP 
was added $>2.5 \mu \mathrm{g} / \mathrm{mL}$. They also discovered that the fractioned SP with $\mathrm{MW}>30 \mathrm{kDa}$ was cytotoxic at concentration doses as low as $1 \mathrm{mg} / \mathrm{mL}$, while SP fractions with MW concentrations of 10-30 kDa and 3-10 kDa were non-cytotoxic, even at the maximum dosage $(10 \mu \mathrm{g} / \mathrm{mL})$. Human breast cancer cells (MCF-7), human hepatocellular carcinoma cells (HepG2), human normal fibroblasts (HFB4), breast cancer cells (MDA-MB231), and hepatocellular carcinoma (HCC) all demonstrated that the dose-dependent reduction in cell viability was dependent on the concentration of the extracts and the duration of the contact time $[49,50]$. The $\mathrm{IC}_{80}$ value of JFFH, JFAH, and JFPH was $2.5 \mu \mathrm{g} / \mathrm{mL}$. Therefore, jellyfish hydrolysate demonstrated low toxicity to $\mathrm{HaCaT}$ at this concentration. However, further research is still required in order to assess the potential of jellyfish hydrolysate as functional ingredient in different applications.

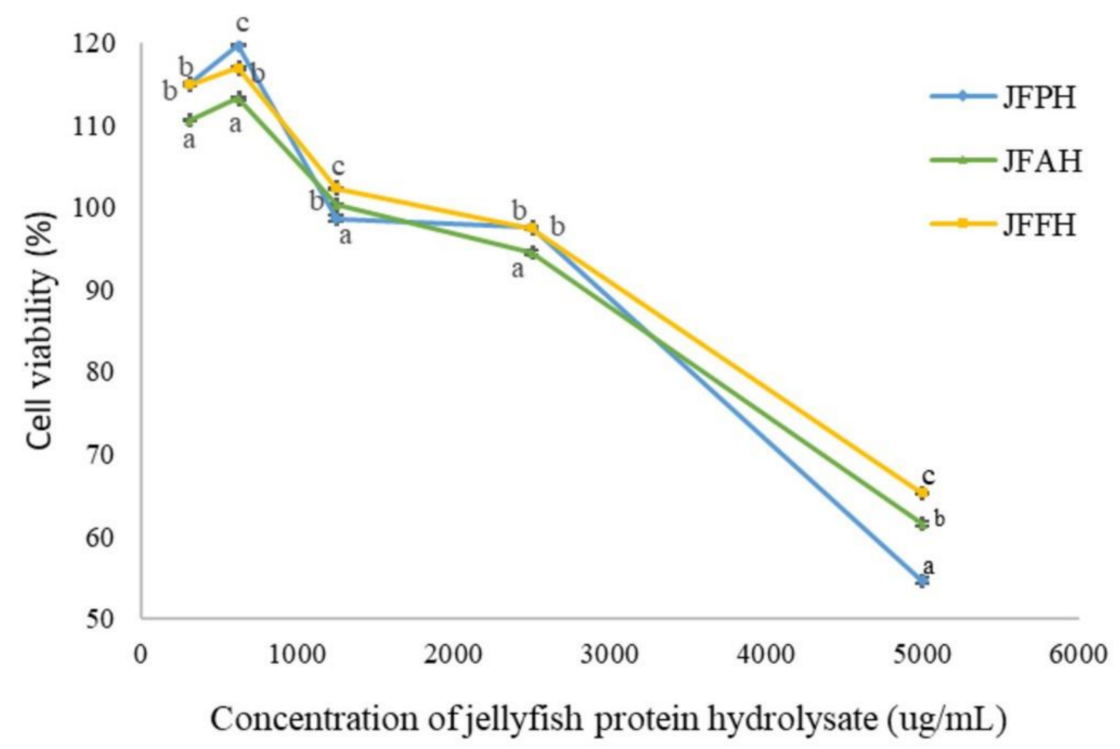

Figure 4. Cytotoxic effect of jellyfish hydrolysate prepared with alcalase (JFAH), flavourzyme (JFFH), and papain (JFPH) on human keratinocytes cells (HaCaT) at $24 \mathrm{~h}$ incubation.

\subsection{Fractionation of JFFH}

The JFFH was fractionated into four fractions: fraction-I (>10 kDa), fraction-II (3-10 kDa), fraction-III (1-3 kDa), and fraction-IV $(<1 \mathrm{kDa})$, to identify which fractions exhibit functional properties. Table 5 showed the yield, antioxidant properties, and tyrosinase inhibition activity for each fraction. Fraction-III had the highest antioxidant activity and tyrosinase inhibition activity $(p \leq 0.05)$. These results are consistent with those determined by Mongkonkamthorn et al. [17] and Mongkonkamthorn et al. [19], who demonstrated that peptides with $<1 \mathrm{kDa}$ MW from tuna blood and dark meat had the strongest antioxidant activity. Zhuang et al. [12] reported jellyfish hydrolysate fraction HF-2 (1-3 kDa) has a tyrosinase inhibitory effect that is higher than $50 \%$ at $5 \mathrm{mg} / \mathrm{mL}$ as well as strong $\mathrm{Cu}^{2+}$ chelating activity. Prakot et al. [51] also reported a possible tyrosinase inhibitor in spotted babylon protein hydrolysate $(\mathrm{MW}<5 \mathrm{kDa})$, reporting an $\mathrm{IC}_{50}$ value of $0.075 \mu \mathrm{g} / \mathrm{mL}$.

Table 5. Antioxidant and tyrosinase inhibition activity and yield from the fractionation of jellyfish hydrolysates using flavourzyme.

\begin{tabular}{|c|c|c|c|c|c|c|}
\hline \multirow[b]{2}{*}{ MW (kDa) } & \multicolumn{6}{|c|}{ Responses } \\
\hline & Fraction & $\begin{array}{c}\operatorname{ABTS}\left(\mathrm{IC}_{50}\right) \\
(\mathrm{mg} / \mathrm{mL})\end{array}$ & $\begin{array}{c}\text { DPPH }\left(\mathrm{IC}_{50}\right) \\
(\mathrm{mg} / \mathrm{mL})\end{array}$ & $\begin{array}{l}\text { FRAP }(\mathrm{mmol} \\
\left.\mathrm{FeSO}_{4} / \mathrm{g}\right)\end{array}$ & $\begin{array}{c}\text { Tyrosinase } \\
\text { Inhibitory }\left(\mathrm{IC}_{50}\right) \\
(\mathrm{mg} / \mathrm{mL})\end{array}$ & Yield (\%) \\
\hline$>10 \mathrm{kDa}$ & I & $2.91^{c} \pm 0.01$ & $3.71^{\mathrm{c}} \pm 0.11$ & $0.65^{c} \pm 0.001$ & $14.2^{b} \pm 8.49$ & $3.01^{\mathrm{d}} \pm 0.01$ \\
\hline $10-3 \mathrm{kDa}$ & II & $1.15^{b} \pm 0.01$ & $0.85^{\mathrm{a}} \pm 0.03$ & $0.27^{b} \pm 0.001$ & $9.35^{a} \pm 0.27$ & $2.18^{c} \pm 0.02$ \\
\hline $3-1 \mathrm{kDa}$ & III & $0.91^{\mathrm{a}} \pm 0.01$ & $0.95^{\mathrm{a}} \pm 0.04$ & $0.24^{\mathrm{a}} \pm 0.001$ & $8.95^{\mathrm{a}} \pm 0.01$ & $1.89^{b} \pm 0.00$ \\
\hline$<1 \mathrm{kDa}$ & IV & $0.89^{\mathrm{a}} \pm 0.01$ & $1.11^{\mathrm{b}} \pm 0.01$ & $0.28^{b} \pm 0.01$ & $12.6^{b} \pm 0.14$ & $0.73^{\mathrm{a}} \pm 0.00$ \\
\hline
\end{tabular}

Note: Mean \pm SD, DPPH and ABTS radical scavenging activity, FRAP value and tyrosinase inhibitory activity different letters in the same variables show significant differences $(p \leq 0.05)$. 


\subsection{Gel Filtration Chromatography}

As represented in Figure 5A, the fraction-III of JFFH was further isolated using a Sephadex G-25 column. The peptide bonds and the proteins, peptides, or amino acids with aromatic rings were able to be monitored using $\mathrm{A}_{220}$ and $\mathrm{A}_{280}$, respectively [52]. Many individual peaks were observed at $\mathrm{A}_{280}$, indicating the presence of aromatic peptide or amino acid side chains. Fraction-III showed the same distinct peaks at $A_{220}$ and $A_{280}$ in fraction no. 97, which may indicate the presence peptide linkages and that aromatic amino acids rings are abundant (tyrosine and tryptophan). The DPPH and ABTS radical scavenging activity as well as the FRAP value (Figure 5B) and the tyrosinase inhibitory activity of the fractions (Figure 5C) were all investigated. Different fractions showed varying degrees of antioxidant activity and tyrosinase inhibition. Fraction no. 42, which exhibited the highest FRAP activity, contained peptides with an MW of 21,397 Da. The highest DPPH radical scavenging activity was shown in fraction no. 95 (peptide with MW of $807 \mathrm{Da}$ ). The strongest ABTS radical scavenging activity was in the compressed peptides with an MW of $656 \mathrm{Da}$. According to Wu et al. [53], antioxidant peptides from mackerel protein hydrolysate with a molecular weight of $1400 \mathrm{Da}$ had higher activity than peptides with molecular weights of $900 \mathrm{Da}$ or $200 \mathrm{Da}$. Mendis et al. [54] observed the strongest antioxidant activity in peptides from giant squid skin gelatin hydrolysate with an MW less than $3000 \mathrm{Da}$. The isolated peptides from short-sequence and low-MW (538-887 Da) tuna by-product hydrolysate showed strong antioxidant properties that affected the radical values and lipid oxidation inhibition [28]. Therefore, fraction-III, which was isolated from JFFH-containing peptides with an MW of $2448 \mathrm{Da}$, showed the strongest tyrosinase inhibitory activity. The hydrophobic Val, Ala, and/or Leu residues in potent tyrosinase inhibitory peptides are generally combined with Arg and/or Phe [4]. Sea cucumber (B. Vitiensis) demonstrated good tyrosinase inhibitory activity, with an $\mathrm{IC}_{50}$ value of $0.28 \mathrm{mg} / \mathrm{mL}$ [55]. Many studies have revealed that the amino acid composition and molecular weight distribution of certain peptides were associated with their antioxidant activity and strong metal chelation capacity $[4,12,21]$.

(A)

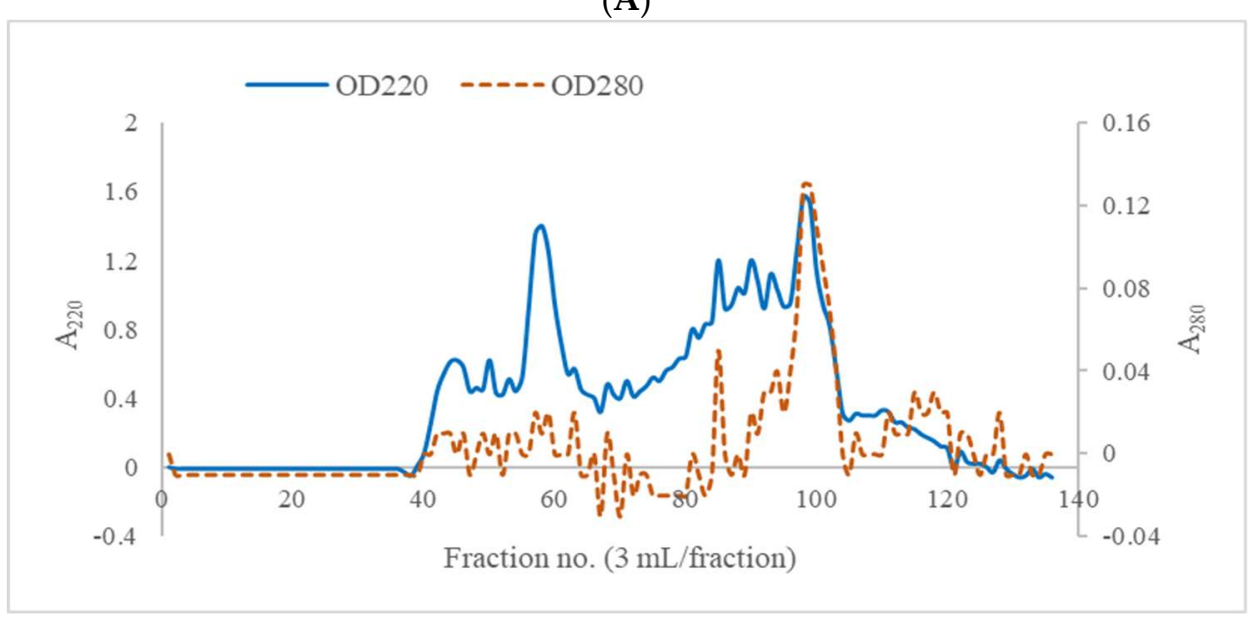

Figure 5. Cont. 
(B)

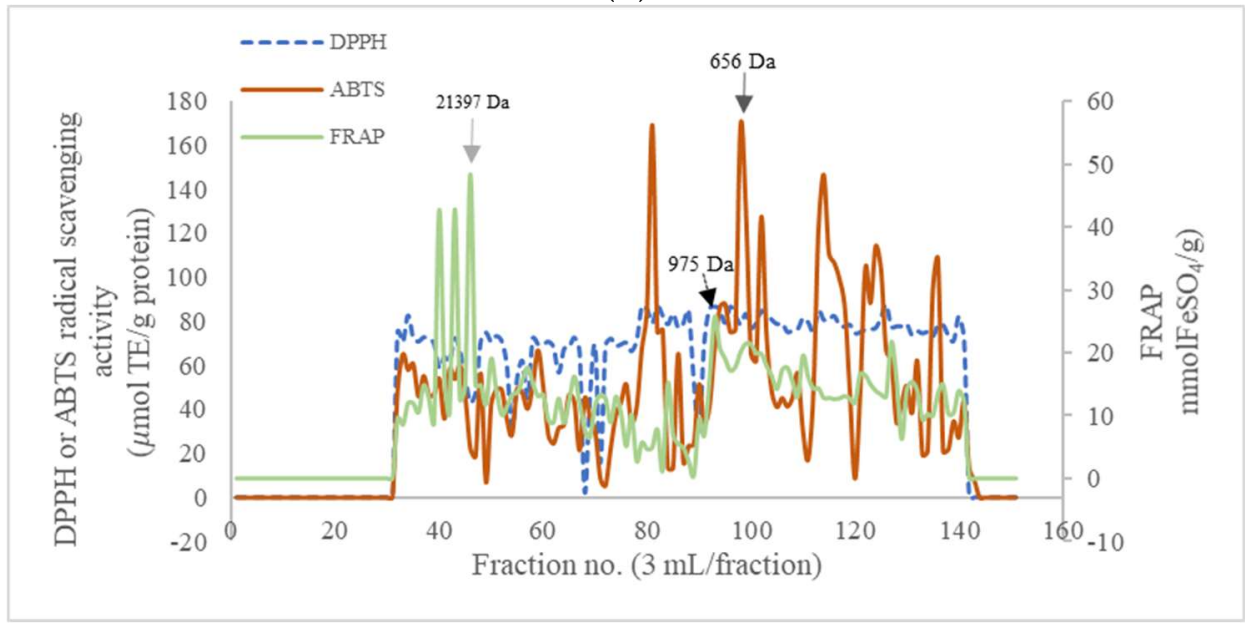

(C)

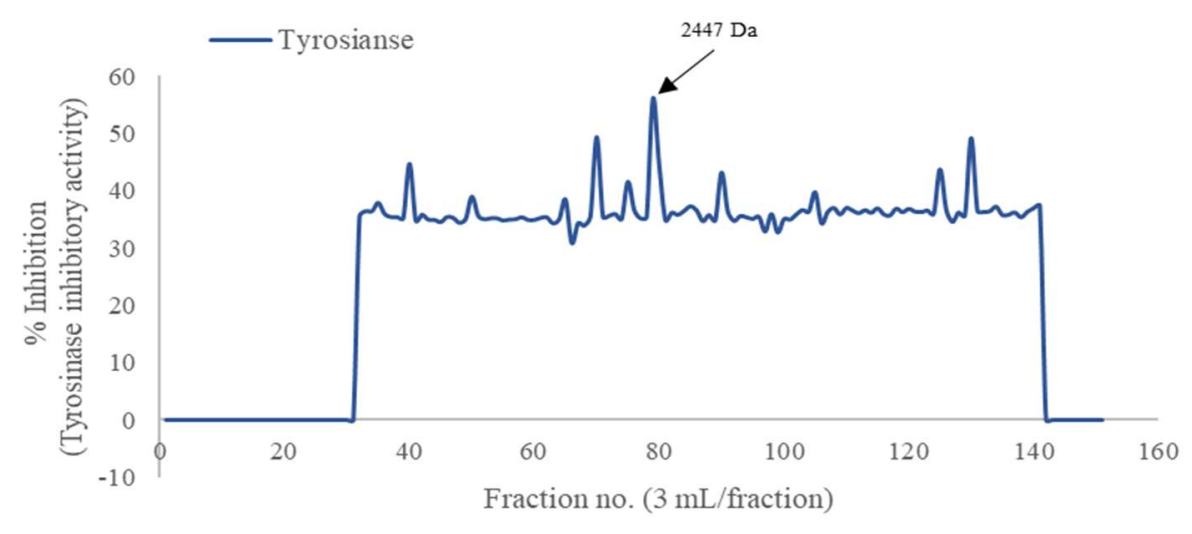

Figure 5. Elution profile of antioxidant and tyrosinase inhibitory peptide from fraction-III (MW 1-3 kDa) from JFFH using Sephadex G-25 gel filtration chromatography monitored at $A_{220}$ and $A_{280}$ (A). DPPH and ABTS radical scavenging and FRAP value (B) and tyrosinase inhibitory activity (C) of the different fractions.

\section{Conclusions}

The optimized conditions for the production of jellyfish hydrolysate using alcalase, flavourzyme, and papain were an enzyme concentration of $5 \%$, with hydrolysis times of $360 \mathrm{~min}$ for alcalase, $345 \mathrm{~min}$ for flavourzyme, and $360 \mathrm{~min}$ for papain. The models that were generated fit the experimental values well. The jellyfish hydrolysate obtained flavourzyme hydrolysis (JFFH) contained hydrophobic and hydrophilic amino acids, which comprised about about 43 and $57 \%$ of the total amino acids, respectively. The $\mathrm{IC}_{80}$ value for $\mathrm{HaCaT}$ cell viability for JFAH, JFFH, and JFPH was $2.5 \mathrm{mg} / \mathrm{mL}$. The fractionated peptides from JFFH fraction-III (MW of 1-3 kDa) had highest antioxidant activity and strongest tyrosinase inhibition activity. The peptides in JFFH with high ABTS radical scavenging, DPPH radical scavenging, and FRAP values were characterized as having MWs of 656, 807 and 21,397 Da, respectively, while the fractionated peptide with an MW of $2448 \mathrm{Da}$ showed high tyrosinase inhibition activity. Therefore, it is possible to utilize salted jellyfish as a raw material for the preparation of natural antioxidants and as an anti-tyrosinase, meaning that it can potentially be used as functional ingredient in the food, cosmetic, and pharmaceutical industries. 


\begin{abstract}
Author Contributions: Conceptualization, S.W.; methodology, S.W. and M.U.; validation, T.S., S.Y., S.M., J.M.R. and S.W.; formal analysis, M.U.; investigation, M.U. and S.W.; data curation, M.U.; writing-original draft preparation, M.U. and S.W.; writing-review and editing, T.S., S.W., and J.M.R.; supervision, S.Y., S.M., T.S., J.M.R., and S.W.; project administration, S.W.; funding acquisition, S.W. All authors have read and agreed to the published version of the manuscript.
\end{abstract}

Funding: This research work was financial support from the National Research Council of Thailand (NRCT), Chiang Mai University (Thailand), The Graduate School, and College of Maritime Studies and Management, Chiang Mai University.

Institutional Review Board Statement: Not applicable.

Informed Consent Statement: Not applicable.

Data Availability Statement: Data is contained within the article.

Acknowledgments: The authors gratefully acknowledge the financial support from the National Research Council of Thailand (NRCT), Chiang Mai University (Thailand), The Graduate School, and College of Maritime Studies and Management, Chiang Mai University, to the authors to allow them to conduct the practical work reported in this paper.

Conflicts of Interest: The authors declare that they have no conflicts of interest related to this work.

\title{
References
}

1. Song, K.K.; Huang, H.; Han, P.; Zhang, C.H.; Shi, Y.; Chen, Q.X. Inhibitory effects of cis-and trans-isomers of 3,5-dihydroxystilbene on the activity of mushroom tyrosinase. Biochem. Biophys. Res. Commun. 2006, 342, 1147-1151. [CrossRef] [PubMed]

2. Kim, Y.J.; No, J.K.; Lee, J.S.; Kim, M.S.; Chung, H.Y. Antimelanogenic activity of 3,4-dihydroxyacephenone: Inhibition of tyrosinase and MITF. Biosci. Biotechnol. Biochem. 2006, 70, 532-534. [CrossRef] [PubMed]

3. Zolghadri, S.; Bahrami, A.; Khan, M.T.H.; Munoz-Munoz, J.; Garcia-Molina, F.; Garcia-Canovas, F.; Saboury, A.A. A comprehensive review on tyrosinase inhibitors. J. Enzyme Inhib. Med. Chem. 2019, 34, 279-309. [CrossRef] [PubMed]

4. Schurink, M.; van Berkel, W.J.H.; Wichers, H.J.; Boeriu, C.G. Novel peptides with tyrosinase inhibitory activity. Peptides 2007, 28, 485-495. [CrossRef] [PubMed]

5. Husni, A.; Jeon, J.S.; Um, B.H.; Han, N.S.; Chung, D. Tyrosinase inhibition by water and ethanol extracts of a far eastern sea cucumber, Stichopus japonicus. J. Sci. Food Agric. 2011, 91, 1541-1547. [CrossRef] [PubMed]

6. Fan, Q.; Jiang, H.; Yuan, E.D.; Zhang, J.X.; Ning, Z.X.; Qi, S.J.; Wei, Q.J. Tyrosinase inhibitory effects and antioxidative activities of novel cinnamoyl amides with amino acid ester moiety. Food Chem. 2012, 134, 1081-1087. [CrossRef]

7. Ding, J.F.; Li, Y.Y.; Xu, J.J.; Su, X.R.; Gao, X.; Yue, F.P. Study on effect of jellyfish collagen hydrolysate on anti-fatigue and anti-oxidation. Food Hydrocoll. 2011, 25, 1350-1353. [CrossRef]

8. Leone, A.; Lecci, R.M.; Milisenda, G.; Piraino, S. Mediterranean jellyfish as novel food: Effects of thermal processing on antioxidant, phenolic, and protein contents. Eur. Food. Res. Technol. 2019, 245, 1611-1627. [CrossRef]

9. FAO. The State of World Fisheries and Aquaculture 2020. Sustainability in Action; FAO: Rome, Italy, 2020.

10. Kromfang, I.; Chikhunthod, U.; Karpilanondh, P.; Thumthanaruk, B. Identification of volatile compounds in jellyfish protein hydrolysate. KMUTNB Int. J. App. Sci. Tech. 2015, 8, 153-161. [CrossRef]

11. Rodsuwan, U.; Thumthanaruk, B.; Kerdchoechuen, O.; Laohakunjit, N. Functional properties of type A gelatin from jellyfish (Lobonema smithii). Food Sci. Technol. Int. 2016, 23, 507-514.

12. Zhuang, Y.; Sun, L.; Zhao, X.; Wang, J.; Hou, H.; Li, B. Antioxidant and melanogenesis-inhibitory activities of collagen peptide from jellyfish (Rhopilema esculentum). J. Agric. Food Chem. 2009, 89, 1722-1727. [CrossRef]

13. Yu, H.H.; Liu, X.G.; Xing, R.E.; Liu, S.; Guo, Z.Y.; Wang, P.B. In vitro determination of antioxidant activity of proteins from jellyfish Rhopliema esculentum. Food Chem. 2006, 95, 123-130. [CrossRef]

14. Zhuang, Y.; Hou, H.; Zhao, X.; Zhang, Z.; Li, B. Effects of collagen and collagen hydrolysate from jellyfish (Rhopilema esculentum) on mice skin photoaging induced by UV irradiation. J. Food Sci. 2009, 74, 183-188. [CrossRef] [PubMed]

15. Zhang, J.; Duan, R.; Huang, L.; Song, Y.; Regenstein, J.M. Characterisation of acid-soluble and pepsin-solubilised collagen from jellyfish (Cyanea nozakii Kishinouye). Food Chem. 2014, 150, 22-26. [CrossRef]

16. Ahn, C.; Lee, K.; Je, J. Enzymatic production of bioactive protein hydrolysates from tuna liver: Effects of enzymes and molecular weight on bioactivity. J. Food Sci. Technol. 2010, 45, 562-568. [CrossRef]

17. Mongkonkamthorn, N.; Malila, Y.; Regenstein, J.M.; Wangtueai, S. Enzymatic hydrolysis optimization for preparation of tuna dark meat hydrolysate with antioxidant and angiotensin I-converting enzyme (ACE) inhibitory activities. J. Aquat. Food. Prod. Technol. 2021, 30, 1090-1108. [CrossRef]

18. Karami, Z.; Akbari-Adergani, B. Bioactive food derived peptides: A review on correlation between structure of bioactive peptides and their functional properties. J. Food Sci. Technol. 2019, 56, 535-547. [CrossRef] [PubMed] 
19. Mongkonkamthorn, N.; Malila, Y.; Yarnpakdee, S.; Makkhum, S.; Regenstein, J.M.; Wangtueai, S. Production of protein hydrolysate containing antioxidant and angiotensin-I-converting enzyme (ACE) inhibitory activities from tuna (Katsuwonus pelamis) blood. Processes 2020, 8, 1518. [CrossRef]

20. Domenico, S.D.; Rinaldis, G.D.; Paulmery, M.; Piraino, S.; Leone, A. Barrel jellyfish (Rhizostoma pulmo) as source of antioxidant peptides. Marine Drugs 2019, 17, 134. [CrossRef]

21. Aziz, N.A.A.; Salim, N.; Zarei, M.; Saari, N.; Yusoff, F.M. Extraction, anti-tyrosinase, and antioxidant activities of the collagen hydrolysate derived from Rhopilema hispidum. Prep. Biochem. Biotechnol. 2021, 51, 44-53. [CrossRef]

22. Liu, X.; Zhang, M.; Jia, A.; Zhang, Y.; Zhu, H.; Zhang, C.; Sun, Z.; Liu, C. Purification and characterization of angiotensin I converting enzyme inhibitory peptides from jellyfish Rhopilema esculentum. Food Res. Int. 2013, 50, 339-343. [CrossRef]

23. Ahn, C.B.; Kim, J.G.; Je, J.Y. Purification and antioxidant properties of octapeptide from salmon byproduct protein hydrolysate by gastrointestinal digestion. Food Chem. 2014, 147, 78-83. [CrossRef] [PubMed]

24. Wangtueai, S.; Siebenhandl-Ehn, S.; Haltrich, D. Optimization of the preparation of gelatin hydrolysates with antioxidative activity from lizardfish (Saurida spp.) scales gelatin. Chiang Mai J. Sci. 2016, 43, 68-79.

25. Chan, E.W.C.; Lim, Y.Y.; Wong, L.F.; Lianto, F.S.; Wong, S.K.; Lim, K.K.; Loe, C.E.; Lim, T.Y. Antioxidant and tyrosinase inhibition properties of leaves and rhizomes of ginger species. Food Chem. 2008, 109, 477-483. [CrossRef]

26. Herbert, P.; Barros, P.; Ratola, N.; Alves, A. HPLC determination of amino acids in must and port wine using OPA/FMOC derivatives. J. Food Sci. 2000, 65, 1130-1133. [CrossRef]

27. Pastorino, G.; Marchetti, C.; Borghesi, B.; Cornara, L.; Ribulla, S.; Burlando, B. Biological activities of the legume crops Melilotus officinalis and Lespedeza capitata for skin care and pharmaceutical applications. Ind. Crop. Prod. 2017, 96, 158-164. [CrossRef]

28. Hsieh, Y.H.P.; Leong, F.M.; Rudloe, J. Jellyfish as food. Hydrobiologia 2001, 451, 11-17. [CrossRef]

29. Leone, A.; Lecci, R.M.; Durante, M.; Meli, F.; Piraino, S. The bright side of gelatinous blooms: Nutraceutical value and antioxidant properties of three Mediterranean jellyfish (Scyphozoa). Marine Drugs. 2015, 13, 4654-4681. [CrossRef] [PubMed]

30. Muangrod, P.; Charoenchokpanich, W.; Rungsardthong, V.; Vatanyoopaisan, S.; Wonganu, B.; Roytrkul, S.; Thumthanaruk, B Effect of pepsin hydrolysis on antioxidant activity of jellyfish protein hydrolysate. EDP Sci. 2021, 302, 02010. [CrossRef]

31. Wangtueai, S.; Phimolsiripol, Y.; Vichasilp, C.; Regenstein, J.M.; Schoenlechner, R. Optimization of gluten-free functional noodles formulation enriched with fish gelatin hydrolysates. LWT-Food Sci. Tech. 2020, 133, 10997. [CrossRef]

32. Halim, N.R.A.; Sarbon, N.M. A response surface approach on hydrolysis condition of eel (Monopterus sp.) protein hydrolysate with antioxidant activity. Int. Food Res. J. 2017, 24, 1081-1093.

33. Prabha, J.; Narikimelli, A.; Sajini, M.I.; Vincent, S. Optimization for autolysis assisted production of fish protein hydrolysate from underutilized fish Pellona ditchela. Int. J. Energy Res. 2013, 4, 1863-1869.

34. Slizyte, R.; Rommi, K.; Mozuratyte, R.; Eck, P.; Five, K.; Rusta, T. Bioactivities of fish protein hydrolysates from defatted salmon backbone. Biotechnol. J. 2016, 11, 99-109. [CrossRef] [PubMed]

35. Je, J.Y.; Lee, K.H.; Ahn, C.B. Antioxidant and antihypertensive protein hydrolysate produced from tuna liver by enzymatic hydrolysis. Food Res. Int. 2009, 42, 1266-1272. [CrossRef]

36. Yarnpakdee, S.; Benjakul, S.; Kristinsson, H.G.; Kishimura, H. Antioxidant and sensory properties of protein hydrolysate derived from Nile tilapia (Oreochromis niloticus) by one-and two-step hydrolysis. J. Food Sci. Technol. 2015, 53, 3336-3349. [CrossRef] [PubMed]

37. Molla, A.E.; Hovannisyan, H.G. Optimization of enzymatic hydrolysis of visceral waste proteins of beluga Huso huso using Protamex. Int. Aquat. Res. 2011, 3, 93-99.

38. Saidi, S.; Deratani, A.; Amar, R.B.; Belleville, M.P. Fractionation of tuna dark muscle hydrolysate by a two-step membrane process Sep. Purif. Technol. 2013, 108, 28-36. [CrossRef]

39. Shun, L.; Lin, L.; Wei, X.; Jian-Feng, L.; Ying-Wang, Y.; Shao-Tong, J. Optimization of hydrolysis conditions of gelatin from channel catfish skin. Food Sci. 2013, 34, 156-160.

40. Li, B.; Chen, F.; Wang, X.; Ji, B.P.; Wu, Y. Isolation and identification of oxidative peptides from porcine collagen hydrolysate by consecutive chromatography and electrospray ionization mass spectrometry. Food Chem. 2007, 102, 1135-1143. [CrossRef]

41. Saidi, V.M.; Deratani, A.; Belleville, M.P.; Amar, R.B. Antioxidant properties of peptide fractions from tuna dark muscle protein by-product hydrolysate produced by membrane fractionation process. Food Res. Int. 2014, 65, 329-336. [CrossRef]

42. Tavano, O.L. Protein hydrolysis using proteases: An important tool for food biotechnology. J. Mol. Catal. B Enzym. 2013, 90, 1-11. [CrossRef]

43. Nasri, R.; Jridi, M.; Lassoued, I.; Jemil, I.; Ben Slama-Ben Salam, R.; Nasri, M.; Karra-Haabouni, M. The influence of the extent of enzymatic hydrolysis in antioxidative properties and ACE-inhibitory activity of protein hydrolysate by goby (Zosterisessoe ophiocephalus) muscle. Appl. Biochem. Biotechnol. 2014, 173, 1121-1134. [CrossRef] [PubMed]

44. Karioti, A.; Protopappa, A.; Megoulas, N.; Skaltsa, H. Identification of tyrosinase inhibitors from Marrubrium velutinum and Marrubium cylleneum. Bioorg. Med. Chem. 2007, 15, 2708-2714. [CrossRef]

45. Masuda, T.; Yamshita, D.; Takeda, Y.; Yonemori, S. Screening for tyrosinase inhibitors among extracts of seashore plants and identification of potent inhibitors from Garcinia subelliatica. Biosci. Biotechnol. Biochem. 2005, 69, 197-201. [CrossRef] [PubMed]

46. Samarayanaka, A.G.P.; Li-Chan, E.C.Y. Autolysis-assisted production of (FPH) with antioxidant properties from Pacific hake (Merluccius productus). Food Chem. 2008, 107, 768-776. [CrossRef] 
47. Picot, L.; Ravallec, R.; Fouchereau-Peron, M.; Vandanjon, L.; Jaouen, P.; Chaplain-Derouiniot, M.; Guerard, F.; Chabeaud, A.; LeGal, Y.; Alvarez, O.M.; et al. Impact of ultrafiltration and nanofiltration of an industrial fish protein hydrolysate on its bioactive properties. J. Sci. Food Agric. 2010, 90, 1819-1826. [CrossRef]

48. Wu, Z.; Fernandez-Lima, F.A.; Russell, D.H. Amino acid Influence on copper binding to peptides: Cysteine versus arginine. J. Am. Soc. Mass Spectrom. 2010, 21, 522-533. [CrossRef] [PubMed]

49. Leone, A.; Lecci, R.M.; Durante, M.; Piraino, S. Extract from the zooxanthellate jellyfish Cotylorhiza tuberculate modulates gap junction intercellular communication in human cell cultures. Marine Drugs 2013, 11, 1728-1762. [CrossRef] [PubMed]

50. Villanueva, A. Hepatocellular carcinoma. N. Engl. J. Med. 2019, 380, 1450-1462. [CrossRef]

51. Prakot, P.; Chaitanawisuti, N.; Karnchanatat, A. In vitro anti-tyrosinase activity of protein hydrolysate from spotted babylon (Babylonia areolata). Food Appl. Biosci. J. 2015, 3, 109-120.

52. Klompong, V.; Bemjakul, S.; Yachai, M.; Visessangun, W.; Shahidi, F.; Hayes, K. Amino acid composition and antioxidative peptides from protein hydrolysates of yellow stripe trevally (Selaroides leptolepis). J. Food Sci. 2009, 74, C126-C133. [CrossRef]

53. Wu, H.C.; Chen, H.M.; Shiau, C.Y. Free amino acids and peptides as related to antioxidant properties in protein hydrolysates of mackerel (Scomber austriasicus). Food Res. Int. 2003, 36, 949-957. [CrossRef]

54. Mendis, E.; Rajapakse, N.; Byun, H.G.; Kim, S.K. Investigation of jumbo squid (Dosidicus gigas) skin gelatin peptides for their in vitro antioxidant effects. Life Sci. 2005, 77, 2166-2178. [CrossRef] [PubMed]

55. Nursid, M.; Marraskuranto, E.; Kuswardini, A.; Winanto, T. Screening of tyrosinase inhibitor, antioxidant and cytotoxicity of dried sea cucumber from Tomoni Bay, Indonesia. Pharmacogn. J. 2019, 11, 555-558. [CrossRef] 